\title{
WORKS GITED
}

In light of the unstable nature of many websites and to ensure the continuing availability of online resources cited in China-related research, DACHS Leiden now hosts citation repositories containing downloads of websites and web pages as they were originally accessed for the project in question. A citation repository for this book, created in February 2008, is found at http://leiden.dachs-archive.org/citrep/vancrevel2008/. Its back-up function aside, this has made it unnecessary to include lengthy URLs in the list below. If search engines, website names and occasional click-through directions provided in the bibliography don't suffice to find the material in its original form, the reader may wish to turn to the repository instead.

All unofficial publications are identified as such. Information on unofficial poetry journals is available from the dedicated bibliography mentioned in the preface (Van Crevel 2007).

Interviews are identified as such unless their title makes this unnecessary, and listed under the interviewee's name, followed by that of the interviewer, just like co-authored and co-edited articles and books.

Different from the main narrative, the translations of Chinese titles in the list of works cited don't distinguish between "the Eighties" and "the Nineties" as intellectual-cultural periodizations and "the 1980s" and "the 1990s" as indications of calendar time, but literally follow the originals, for reasons of bibliographical accuracy that also inform the use of simplified and full-form characters.

Abrams, M H. 1971: The Mirror and the Lamp: Romantic Theory and the Critical Tradition, London etc: Oxford UP (first edition 1953)

Alvarez, A. 1971: The Savage God: A Study of Suicide, London: Weidenfeld \& Nicolson An et al (eds). 2004: An Qi, Yuancun \& Huang Lihai 安琪、远村、黄礼孩, 《中间代 诗全集》[Collected Poems of the Middle Generation], 共二册, 福州: 海峡文艺 Ang, Ien. 2001: On Not Speaking Chinese: Living between Asia and the West, London etc: Routledge

Ash, Adrienne. 1982: "Lyric Poetry in Exile," in Spalek \& Bell 1982: 1-18

Attridge, Derek. 1981: "The Language of Poetry: Materiality and Meaning," in Essays in Criticism 31-3: 228-245 
Aviram, Amittai. 1994: Telling Rhythm: Body and Meaning in Poetry, Ann Arbor: University of Michigan Press

Bailey, Alison. 2006: review of David Der-wei Wang, The Monster That Is History: History, Violence, and Fictional Writing in Twentieth-Century China, MCLC Resource Center $\rightarrow$ Book Reviews (online, see also p475)

Barmé, Geremie. 1999: In the Red: On Contemporary Chinese Culture, New York: Columbia UP

\& Jaivin, Linda (eds). 1992: New Ghosts, Old Dreams: Chinese Rebel Voices, New York: Times Books / Toronto: Random House

Barnstone, Tony (ed). 1993: Out of the Howling Storm: The New Chinese Poetry, various translators, Hanover etc: Wesleyan UP

Baudelaire, Charles. 1943: Le spleen de Paris: petits poèmes en prose, suivis des journaux intimes et de choix de maximes consolantes sur l'amour [Paris Spleen: Little Poems in Prose, Followed by the Intimate Journals and a Choice of Consoling Maxims on Love], Paris: Éditions de Cluny

1989: Charles Baudelaire, The Parisian Prowler: Le Spleen de Paris: Petits Poèmes en prose, translated by Edward K Kaplan, Athens GA etc: University of Georgia Press

Beach, Sophie. 2001: "Straining at the Leash: China's Journalists Battle Local Interests and Censorship to Get the News Out," in China Rights Forum, fall 2001: 12-15, 44

Bei Dao 北岛. 1978: 《陌生的海滩》 [Strange Shores], 北京 (unofficial publication, reprinted 1980)

1983: Notes from the City of the Sun, bilingual, edited and translated by Bonnie S McDougall, Ithaca: Cornell University East Asia Papers (revised edition 1984) -1987: 《北岛诗选》 [Selected Poems by Bei Dao], 广州: 新世纪 (second, expanded edition; first edition 1986)

1988: The August Sleepwalker, translated by Bonnie S McDougall, London: Anvil 1990: "Terugblik van een balling" [An Exile Looking Back], in Carly Broekhuis, Dirk Jan Broertjes, Simon Franke, Simon Gunn \& Bert Janssens (eds), Het collectieve geheugen: over literatuur en geschiedenis [The Collective Memory: On Literature and History], translated by Maghiel van Crevel, Amsterdam: De Balie / The Hague: Novib: 65-79

1991: Old Snow, bilingual, translated by Bonnie S McDougall \& Chen Maiping, New York: New Directions

1994: Forms of Distance, bilingual, translated by David Hinton, New York: New Directions

— 1995: (北島)《午夜歌手: 北島詩選1972-1994》 [Midnight Singer: Selected Poems by Bei Dao (1972-1994)], 台北: 九歌

1996: Landscape over Zero, bilingual, translated by David Hinton with Yanbing Chen, New York: New Directions

1998: (北島)《藍房子》[The Blue House], 台北: 九歌

1999: "From the Founding of Today to Today: A Reminiscence," translated by

Perry Link, Stanford Presidential Lectures in the Humanities and Arts (online, see also p475; republished as "How the 'Revolution' Occurred in Chinese Poetry," in Jefferey Paine [ed], The Poetry of Our World: An International Anthology of Contemporary Poetry, New York: HarperCollins, 2000: 433-437) 2000: Unlock, bilingual, translated by Eliot Weinberger \& Iona Man-Cheong,

New York: New Directions 2003a:《北岛诗歌集》 [Poems by Bei Dao], 海口: 南海 2003b: 《北岛的诗》 [The Poetry of Bei Dao], 长春: 时代文艺 
2004: 《失败之书: 北岛散文》 [The Book of Failure: Short Prose by Bei Dao], 汕头: 汕头大学

\& LaPiana, Siobhan. 1994: "Interview with Visiting Artist Bei Dao: Poet in Exile," in The Fournal of the International Institute 2-1 (online, see also p475)

— \& Tang Xiaodu 唐晓渡. 2003: 《“我一直在写作中寻找方向”: 北岛访谈 录》 ["I've Always Sought Direction from My Writing": An Interview with Bei Dao], in《诗探索》2003-3/4: 164-172

— \& Wedell-Wedellsborg, Anne. 1995: "Secrecy and Truth: An Interview by Anne Wedell-Wedellsborg," in Søren Clausen, Roy Starrs \& Anne WedellWedellsborg (eds), Cultural Encounters: China, Japan and the West, Aarhus: Aarhus UP: 227-240 (dated 1992)

— \& Zha Jianying 查建英. 2006: 〈北岛〉, in Zha 查, 《八十年代访谈录》 [nterviewing the Eighties], 北京: 三联: 66-81 (interview)

\& Zhang-Kubin, Suizi. 1989: Suizi Zhang-Kubin, "Endzeit: Ein Gespräch mit Bei Dao" [End Times: An Interview with Bei Dao], in die horen: Zeitschrift für Literatur, Kunst und Kritik 34-3: 55-58

Beiling 贝岭. 2006: 〈流亡带来了什么一答日本文学刊物《蓝》主编提问〉[What Has Exile Brought? In Response to the Editor of Blue, a Japanese Literary Journal], 獨立中文筆會 / Independent Chinese Pen Center (online, see also p475; revised as Beiling 2007)

2007: 〈流亡中的文学〉 [Literature in Exile], 自由聖火 / Fire of Liberty (online, see also p475; revised edition of Beiling 2006)

Berry. 2005: Michael Berry, "Rupture Writers," in Edward L Davis (ed), Encyclopedia of Contemporary Chinese Culture, London etc: Routledge: 517-518

Bertens. 2001: Hans Bertens, Literary Theory: The Basics, London etc: Routledge

Bevan, David (ed). 1990: Literature and Exile, Amsterdam etc: Rodopi

Birch, Cyril. 1960: "English and Chinese Metres in Hsü Chih-mo," in Asia Major 8: 258-293

Blume, Georg. 2005: "Die Internetpoetin" [The Internet Poetess], in Die Zeit, 24 February 2005

Bourdieu, Pierre. 1993: The Field of Cultural Production: Essays on Art and Literature, edited by Randal Johnson, various translators, Cambridge: Polity Press

Boym, Svetlana. 1998: "Estrangement as a Lifestyle: Shklovsky and Brodsky," in Suleiman 1998: 241-262

Brady, Anne-Marie. 1997: "Dead in Exile: The Life and Death of Gu Cheng and Xie Ye," in China Information xi-4: 126-148

Brems, Hugo. 1991: De dichter is een koe: over poëzie [The Poet Is a Cow: On Poetry], Amsterdam: Arbeiderspers

Brodsky, Joseph. 1973: Selected Poems, translated by George L Kline, Harmondsworth: Penguin

1990: "The Condition We Call 'Exile'," in Glad 1990: 100-130

Bronfen, Elisabeth. 1992: Over Her Dead Body: Death, Femininity and the Aesthetic, Manchester: Manchester UP

Brouwers, Jeroen. 1984: De laatste deur: Essays over zelfmoord in de Nederlandstalige letteren [The Last Door: Essays on Suicide in Dutch-Language Literature], Amsterdam: Synopsis / De Arbeiderspers (first edition 1983)

Brown, Edward. 1984: "The Exile Experience," in Olga Matich with Michael Heim (eds), The Third Wave: Russian Literature in Emigration, Ann Arbor: Ardis: 53-61

Bruno, Cosima. 2003: Contemporary Chinese Poetry in Translation, PhD thesis, School of Oriental and African Studies, University of London

Buruma, Ian. 2000: De neoromantiek van schrijuers in exil [The Neoromanticism of Writers 
in Exile], Amsterdam: Prometheus (translated into English, with minor revisions, as Buruma 2001)

2001: "The Romance of Exile: Real Wounds, Unreal Wounds," in The New Republic, 12 February 2001: 33-38 (translation of Buruma 2000, with minor revisions)

Cai Yi 蔡毅. 1997: 〈诗一非诗: 《0档案》评析〉 [Poetry-Non-Poetry: Review and Analysis of «File 0»], in 《滇池》1997-1: 61-63 1999:《文艺沉思集》[Thoughts on Literature and Art], 昆明: 云南人民

Cao Wenxuan 曹文轩. 2002: 《20 世纪末中国文学现象研究》 [A Study of Phenomena in Chinese Literature at the End of the $20^{\text {th }}$ Century], 北京: 北京大学

Chang Li \& Lu Shourong 常立、卢寿荣. 2002: 《中国新诗》 [China's New Poetry], 上海: 上海人民美术

Che Qianzi. 2003: "Che Qianzi-HOSPITAL ILLUSTRATION 3," film clip by Victor Vroegindeweij \& Daniëlle van Ark, Poetry International Web $\rightarrow$ All Camera Poetica (online, see also p475)

Cheesman, Tom \& Gillespie, Marie. 2002: "Talking Diasporas," in Index on Censorship 31-3: 6-7

Chen Chao 陈超. 1989: 《中国探索诗鉴赏词典》[A Critical Anthology of Chinese Explorative Poetry], 石家庄: 河北人民 (revised and expanded as Chen Chao 1999)

— 1993: 《以梦为马: 新生代卷》 [With a Dream for a Horse: Newborn Generation Volume], 北京: 北京师范大学 (in Xie Mian \& Tang 1993)

1994: 〈王家新诗二首赏析〉 [Appreciations of Two Poems by WangJiaxin], in《诗探索》1994-4: 111-118

- 1999: 《20世纪中国探索诗鉴赏词典》 [A Critical Anthology of 20 $0^{\text {th }}$-Century Chinese Explorative Poetry], 共二册, 石家庄: 河北人民 (revised and expanded edition of Chen Chao 1989)

2003 (ed). 《最新先锋诗论选》[A Selection of Essays on the Newest AvantGarde Poetry], 石家庄: 河北教育

- 2005: 〈贫乏中的自我剥夺: 先锋 “流行诗” 的反文化、反道德问题〉

[Wretched Self-Deprivation: Questions of Anti-Culture and Anti-Morality in "Popular Poetry" of the Avant-Garde], in 《新诗评论》2005-2: 3-10

Chen Dongdong 陈东东. 1991: 〈丧失了歌唱和倾听: 悼海子、骆一禾〉 [The Loss of Song and Ear: In memoriam Haizi and Luo Yihe], in Haizi \& Luo 1991: 337-339 (dated 1989)

1995: (陳東東) 〈魚刺在魚肉中成長: 中國地下詩刊《傾向》始末〉[Fishbones Growing inside Fish-Flesh: The Chinese Underground Poetry Journal Tendency, from Beginning to End], in 《文藝報》(香港) 2: 48-50 (reprinted as 〈《傾向》詩刊創刊始終〉 [The Founding of the Poetry Journal Tendency, from Beginning to End], in 《傾向》10 [1997] : 283-288)

Chen Qufei 陳去飛. 1995: “搞怪” 就是“前衛”: 大陸詩作于堅《0檔案》深度批 評〉 ["Misbehaving" Will Make You "Avant-Garde": An In-Depth Critique of the Mainland-Chinese Poem «File 0» by Yu Jian], in《臺灣詩學季刊》12: 44-59 and 13: 43-46

Chen Sihe 陈思和. 1997: 〈无名的时代: 九十年代中国小说〉 [The Nameless Era: Chinese Fiction in the 1990s], in Wan Zhi 1997a: 58-57

Chen Xuguang 陈旭光. 1996: 《诗学: 理论与批评》 [Poetics: Theory and Criticism], 天津: 百花文艺

Chen Zhongyi 陈仲义. 1993: 〈第三代与朦胧诗之比较〉 [A Comparison of the Third Generation and Obscure Poetry], in 《作家》1993-12: 74-77 
1994: 《诗的哗变：第三代诗面面观》[A Mutiny of Poetry : Perspectives on Third Generation Poetry], 厦门: 鹭江

- 1996: 《中国朦胧诗人论》[On China's Obscure Poets], 南京: 江苏文艺 2000:《扇形的展开: 中国现代诗学谫论》 [Unfold Like a Fan: A Shallow

Treatise on Modern Chinese Poetics], 杭州: 浙江文艺 2002a: 〈大陆先锋诗歌 (1976-2001) 四种写作向度〉 [Four Directions in Mainland Avant-Garde Poetry Writing (1976-2001)], in《诗探索》2002-1/2: $115-125$

2002b: 〈肉身化诗写刍议〉 [A Modest Proposal on Corporealized Poetry Writing], in 《蓝》6: 148-157

Chen Zishan 陈子善 (ed). 1993:《诗人顾城之死》[The Death of Poet Gu Cheng], 上海: 上海人民

Cheng Guangwei 程光炜. 1993:〈王家新论〉 [On Wang Jiaxin], in《南方诗 志》1993 秋: 58-67 (unofficial publication, reprinted in Cheng 程, 《雨中听 枫: 文坛回忆与批评》[Hearing Maples in the Rain: Memoirs and Critique of the Literary Scene], 武汉: 湖北教育, 2000: 168-184, as〈跨时代的写作〉

[Trans-Epoch Writing]; and in Cheng 程, 《程光炜诗歌时评》 [Cheng Guangwei on Current Issues in Poetry], 开封: 河南大学, 2002: 165-179, as〈王家新 论〉 [On Wang Jiaxin])

- 1997a:〈90年代诗歌: 叙事策略及其它〉 Poetry of the 90s: Narrative Strategies and Other Things], in 《大家》1997-3: 137-143

- 1997b:〈叙事及其它〉 [Narrative and Other Things], in Sun 1997: 5-8

- (ed) 1998a: 《岁月的遗照: 九十年代文学书系, 诗歌卷》 [A Portrait of Years Gone By: Literature of the Nineties, Poetry Volume], 北京: 社会科学文献

1998b: 〈不知所终的旅行〉 Journey with Unknown Destination], in Cheng 1998a: 1-20

1999: 〈现成的诗歌与可能的诗歌〉 [Ready-Made Poetry and Possible Poetry], in Cui 1999a: 221-225 (dated 1991)

2003: 《中国当代诗歌史》 [A History of Contemporary Chinese Poetry], 北 京: 中国人民大学

Cheng Weidong 程蔚东. 1987: 〈别了, 舒婷北岛〉 [Farewell, Shu Ting and Bei Dao], in 《文汇报》, 14 January 1987: 3

Chi, Pang-yuan \& Wang, David Der-wei (eds). 2000: Chinese Literature in the Second Half of a Modern Century, Bloomington etc: Indiana UP

Chow, Rey. 1991: Woman and Chinese Modernity, Minneapolis etc: University of Minnesota Press

1993: Writing Diaspora: Tactics of Intervention in Contemporary Cultural Studies, Bloomington etc: Indiana UP

- (ed) 2000: Modern Chinese Literary and Cultural Studies in the Age of Theory: Reimagining a Field, Durham etc: Duke UP

Chuang-tzǔ. 1981: Chuang-tzǔ: The Seven Inner Chapters and Other Writings from the Book Chuang-tzǔ, translated by A C Graham, London etc: George Allen and Unwin

Coelho, Alain. 1995: Arthur Rimbaud fin de la littérature: lecture d'Une saison en enfer [Arthur Rimbaud, the End of Literature: Reading A Season in Hell], Nantes: Joseph K

Cooper, G Burns. 1998: Mysterious Music: Rhythm and Free Verse, Stanford: Stanford UP

Crespi, John. 2001: "The Lyric and the Theatric in Mao-Era Poetry Recitation," in Modern Chinese Literature and Culture 13-2: 72-110

2005: "The Poetry of Slogans and Native Sons: Observations on the First China Poetry Festival," MCLC Resource Center $\rightarrow$ Publications (online, see also p475) 
2007a: "Poetic Memory: Recalling the Gultural Revolution in the Poems of Yu Jian and Sun Wenbo," in Lupke 2007: 165-183 and 219-232

-2007b: Jiang Keping 江克平, 《从 “运动” 到 “活动”: 诗朗诵在当代中国的

价值〉 [From "Movement" to "Event": The Value of Poetry Recitation in Contemporary China], translated by Wu Hongyi 吴弘毅, in 《新诗评论》2007-2: 3-19

— \& Tsou, Zona Yi-ping. 2007: "An Interview with John Crespi on Performance Poetry in China, with a Sampling of Live Recordings," in Full Tilt 2 (online, see also p475)

Cui Weiping 崔卫平. 1992: 〈西川: 超度亡灵〉 [Xi Chuan: Releasing the Souls of the Dead], in 《现代汉诗》1992秋冬: 118-123 (reprinted in Xi Chuan 1997d: 5-9)

— (ed) 1999a: 《不死的海子》 [The Undying Haizi], 北京: 中国文联

- 1999b: 〈真理的祭奠〉 [In Memory of Truth], in Cui 1999a: 89-98 (dated 1992) 1992)

Culler, Jonathan. 1981: The Pursuit of Signs: Semiotics, Literature, Deconstruction, London etc: Routledge \& Kegan Paul 1997: Literary Theory: A Very Short Introduction, Oxford: Oxford UP

DACHS poetry chapter: Leiden University division of the Digital Archive of Chinese Studies (DACHS Leiden) $\rightarrow$ Poetry (online, see also p475)

Daruvala, Susan. 1993: "Zhou Zuoren: 'At Home' in Tokyo," in Lee (Gregory) 1993a: $35-54$

Day, Michael Martin. 2005a: China's Second World of Poetry: The Sichuan Avant-Garde, 1982-1992, Leiden: DACHS poetry chapter $\rightarrow$ China's Second World of Poetry (online, see also p475)

2005b: "China's Second World of Poetry: The Grand Poetry Exhibition of 1986," DACHS poetry chapter $\rightarrow$ China's Second World of Poetry $\rightarrow$ Related material (online, see also p475)

2007a: "Online Avant-Garde Poetry in China Today," in Lupke 2007: 201-217 and 219-232

2007b: "On Paper or Online, or Both?," paper presented at the annual RMMLA conference, Calgary

De Meyer, Jan A M. 1996: "Voorwoord" [Foreword], in Yu Jian, Poëzie als incident: gedichten van 1982 tot 1995 [Poetry as Incident: Poems from 1982 to 1995], translated by Jan A M De Meyer, Gent: Poëziecentrum: 5-9

De Roder, J H. 1999: Het schandaal van de poëzie [The Scandal of Poetry], Nijmegen: Vantilt / Wintertuin

DeFrancis, John (ed). 1996: ABC Chinese-English Dictionary, Honolulu: University of Hawai'i Press

Denton, Kirk A (ed). 1996: Modern Chinese Literary Thought: Writings on Literature, 18931945, Stanford: Stanford UP

1999: editor's note to Modern Chinese Literature and Culture 11-2

2003: "Literature and Politics: Mao Zedong's 'Talks at the Yan'an Forum on Art and Literature'," in Mostow et al 2003: 463-469

Duoyu 朵渔. 2000: 〈是干, 而不是搞〉 [It's Do, Not Make], in 《下半身》1: 114117

Duoduo 多多. 1989: Looking Out from Death: From the Cultural Revolution to Tiananmen Square, translated by Gregory Lee \& John Cayley, London: Bloomsbury 2005:《多多诗选》[Selected Poems by Duoduo], 广州: 花城 
Eagleton, Terry. 1996: Literary Theory: An Introduction, second, revised edition, Oxford: Blackwell

Easthope, Antony. 1983: Poetry as Discourse, London etc: Methuen

Edmond, Jacob. 2004: "Locating Global Resistance: The Landscape Poetics of Arkadii Drogomoshchenko, Lyn Hejinian and Yang Lian," in AUMLA: Fournal of the Australasian Universities Language \& Literature Association 101: 71-98

2005a: "Beyond Binaries: Rereading Yang Lian's 'Norlang' and 'Banpo'," in Fournal of Modern Literature in Chinese 6-1: 152-169

2005b: “Yang Lian and the Globalization of Poetry," paper presented at 中国 新诗: 百年国际研讨会 (北京大学、首都师范大学举办), 18-20 August 2005

2006: "Dissidence and Accommodation: The Publishing History of Yang Lian from Today to Today," in The China Quarterly 185: 111-127

_ 2008a: "A Poetics of Translocation: Yang Lian's Auckland and Lyn Hejinian's Leningrad," in Chris Prentice, Henry Johnson \& Vijay Devadas (eds), Cultural Transformations: Perspectives on Translocation in a Global Age, forthcoming

_ 2008b: "The Flâneur in Exile," unpublished manuscript

\& Chung, Hilary. 2006: "Yang Lian, Auckland and the Poetics of Exile," in Yang Lian 2006: 1-23

Edwards, Robert. 1988: "Exile, Self, and Society," in Lagos-Pope 1988: 15-31

Eliot, T S. 1990: "The Music of Poetry," in Eliot, On Poetry and Poets, London: Faber \& Faber: 28-38 (first published 1942)

Emerson, Andrew G. 2001: "The Guizhou Undercurrent," in Modern Chinese Literature and Culture 13-2: 111-133

2004: "Poet's Life - Hero's Life," in Huang Xiang, A Bilingual Edition of Poetry out of Communist China, translated by Andrew G Emerson, Lewiston etc: Edwin Mellen Press: 1-37

Eoyang, Eugene Chen. 1998: "Tianya, the Ends of the World or the Edge of Heaven: Comparative Literature at the Fin de Siècle," in Zhang Yingin 1998: 218-232, 280-282

Fang Xiang 方向. 1997: 《挽留: 方向詩集》 [Urge the Guest to Stay: Poems by Fang Xiang], edited by Xu Yi 胥式, 香港: 香港金陵書社

Ferry, Megan M. 2003: "Marketing Chinese Women Writers in the 1990s, or the Politics of Self-Fashioning," in Journal of Contemporary China 12-37: 655-675

Findeisen, Raoul David. 1999: "Two Works-Hong (1930) and Ying'er (1993) as Indeterminate Joint Ventures," in Li Xia 1999: 135-178

Finkel, Donald (ed \& transl). 1991: A Splintered Mirror: Chinese Poetry from the Democracy Movement, with additional translations by Carolyn Kizer, San Francisco: North Point Press

Forrest-Thomson, Veronica. 1978: Poetic Artifice: A Theory of Twentieth-Century Poetry, Manchester: Manchester UP

Frye, Northrop. 1973: Anatomy of Criticism: Four Essays, Princeton: Princeton UP (first edition 1957)

1965: Northrop Frye, "Verse and Prose," in Preminger 1965: 885-890

Fu Mahuo 符马活 (ed). 2002: 《诗江湖: 2001 网络诗歌年选: 先锋诗歌档案》 [Poetry Vagabonds: Selected Web Poetry from 2001: The Avant-Garde Poetry Files], 西宁: 青海人民

Gao Bo 高波. 2003: 《解读海子》 [nterpreting Haizi], 昆明: 云南人民 2005: 《现代诗人和现代诗》 [Modern Poets and Modern Poetry], 昆明: 云 南／云南人民 
Gao Xingjian \& Yang Lian 高行健、杨炼. 1994: 〈漂泊使我们们获得了什么? 杨炼 $(\mathrm{Y})$ 和高行健 $(\mathrm{G})$ 的对话〉 [What Have We Gained from Wandering? A Dialogue of Yang Lian and Gao Xingjian], in Yang Lian \& Yo Yo 1994: 293-327 (reprinted in Yang Lian 1998b: 323-367; for German, Italian and [abridged] English translations, see Gao \& Yang 2001a, 2001b and 2002)

2001a: Was hat uns das Exil gebracht? Ein Gespräch zwischen Gao Xingjïan und Yang Lian über chinesische Literatur [What Has Exile Brought Us? A Conversation on Chinese Literature between Gao Xingjian and Yang Lian], translated by Peter Hoffmann, Berlin: DAAD Berliner Künstlerprogramm

2001b: Il pane dell'esilio: La letteratura cinese prima e dopo Tienanmen [The Bread of the Exile: Chinese Literature before and after Tiananmen], translated by Gianni Santamaria, Milan: Medusa

2002: "The Language of Exile: When Pain Turns to Gain," translated by Ben Carrdus, in Index on Censorship 31-3: 112-120

Ge Mai 戈麦. 1993:《彗星: 戈麦诗集》[Comet: Poems by Ge Mai], edited by Xi Du 西渡, 上海: 上海三连

C 1999: 《戈麦诗全编》[The Complete Poems of Ge Mai], edited by Xi Du 西 渡, 上海: 上海三连

Geng Zhanchun 耿占春. 1999: 〈没有故事的生活: 从王家新的《回答》看当代诗 学的叙事问题〉 [Life without a Story: Wang Jiaxin's «Answer» and the Question of Narrative in Contemporary Poetics], in 《当代作家评论》1999-6: 113-120 (reprinted in Geng 耿, 《中魔的镜子》[A Mirror Possessed], 上海: 学林, 2002: 232-248)

Gerbrandy, Piet. 1995: "Pindarus en free jazz, of: Hoe classificeer je poëzie?" [Pindar and Free Jazz, or: How Do You Classify Poetry?], in Hollands Maandblad 1995-4: $13-20$

1999: "De muur: over poëtica, pornografie en innerlijke noodzaak" [The Wall: On Poetics, Pornography and the Inner Urge], in Hollands Maandblad 199912: $25-31$

Glad, John (ed). 1990: Literature in Exile, Durham etc: Duke UP

Glazier, Loss Pequeño. 2002: Digital Poetics: The Making of E-Poetries, Tuscaloosa etc: University of Alabama Press

Golden, Séan \& Minford, John. 1990: "Yang Lian and the Chinese Tradition," in Howard Goldblatt (ed), Worlds Apart: Recent Chinese Writing and its Audiences, Armonk NY etc: M E Sharpe: 119-137

Gong Jingran \& Nie Zuoping 龚静染、聂作平 (eds). 2000: 《中国第4代诗人诗 选》[Selected Poems of China's $4^{\text {th }}$ Generation Poets], 成都: 四川文艺

Gu Cheng 顾城. 1995: 《顾城诗全编》 [The Complete Poems of Gu Cheng], edited by Gu Gong 顾工, 上海: 上海三连

2006: 《顾城》 [Gu Cheng], 北京: 人民文学

website: 《顾城之城》(online, see also p475)

Gu Xiang 顾乡. 1994: 《我面对的顾城最后十四天》 [Gu Cheng's Final Fourteen Days as I Faced Them], 北京: 国际文化

Gui Xinghua 桂兴华. 2002: 《青春宣言》 [Manifesto of Youth], 上海: 上海人民

Guo Xiaochuan 郭小川. 1985: 《郭小川诗选》 [Selected Poems by Guo Xiaochuan], 共二册, 北京: 人民文学

Haft, Lloyd (ed). 1989: A Selective Guide to Chinese Literature, 1900-1949: Volume III: The Poem, Leiden etc: Brill 2000: The Chinese Sonnet: Meanings of a Form, Leiden: CNWS

Haizi 海子. 1990:《土地》 [The Land], 沈阳: 春风文艺 
1995: 《海子的诗》 [The Poetry of Haizi], edited by Xi Chuan 西川, 北京:

人民文学 (republished with minor changes as Haizi 2006)

- 1997: 《海子诗全编》 [The Complete Poems of Haizi], edited by Xi Chuan 西川, 上海: 上海三连

2005: Haizi, An English Translation of Poems of the Contemporary Chinese Poet Hai Zi, translated by Zeng Hong, Lewiston etc: Edwin Mellen Press 2006: 《海子》[Haizi], 北京: 人民文学 ( $\approx$ Haizi 1995, with minor changes) \& Luo Yihe 骆一禾. 1991: 《海子、骆一禾作品集》 [Works by Haizi and

Luo Yihe], edited by Zhou Jun \& Zhang Wei 周骏、张维, 南京: 南京

— \& Xi Chuan 西川. 1986:《麦地之翁》[Lord of the Wheatfields], 北京 (unofficial publication)

- website: 《海子 1989》 (online, see also p475)

Han Dong 韩东. 1986: 〈青年诗人谈诗: 韩东〉 [Young Poets on Poetry: Han Dong], in《诗刊》1986-11: 29 51 1988: 〈奇迹和根据〉 [Miracles and Foundations], in 《诗刊》1988-3: 50-

4: $18-20$

- 1991:〈海子: 行动〉 [Haizi: The Act], in Haizi \& Luo 1991: 335-336

1992a: 《白色的石头》[White Stones], 上海: 上海文艺

1992b: (韓東) 〈《他們》, 人和事〉 [The Life and Times of Them], in 《今

天》1992-2: 188-200 (excerpted as 〈《他们》略说〉 [A Few Words on Them ] in《诗探索》1994-1: 159-162)

1995:〈关于诗歌的十条格言或语录〉 [Ten Aphorisms or Sayings on Poetry], in 《他们》9: 85-86 $35-41$

- 1996: 〈从我的阅读开始〉 [Starting from My Reading], in Wan Zhi 1997a:

- 1997: 〈关于诗歌的两千字〉 [Two Thousand Words on Poetry], in《广西 文学》1997-9: 54

1998a:〈韩东论诗〉 [Han Dong on Poetry], in 《诗歌报月刊》1998-2: 6

1998b:〈我的文学宣言〉 [My Literary Manifesto], in 《文友》1998-9: 15

1998c: 〈备忘: 有关 “断裂” 行为的问题〉 [Memorandum: Questions Concerning the "Rupture" Action], in 《北京文学》1998-10: 41-47

1999:〈论民间〉[On the Popular], in He Xiaozhu 何小竹 (ed), 《1999中国 诗年选》 [Selected Chinese Poems of 1999], 西安: 陕西师范大学: 1-18

2002: 《爸爸在天上看我》[Daddy's Watching Me in Heaven], 石家庄: 河 北教育

2007: "Ten Maxims or Utterances Concerning Poetry," translated by Simon Patton, Poetry International Web $\rightarrow$ China $\rightarrow$ All Articles of China (online, see also $\mathrm{p} 475)$

\& \& Chang Li 常立. 2003: 〈关于 “他们” 及其它: 韩东访谈录〉 [On “Them” and Other Things: An Interview with Han Dong], in 《他们论坛》, 26 August 2003: 斑驳文学网 (online, see also p475)

\& \& Liu Ligan \& Zhu Wen 刘立杆、朱文. 1994:〈韩东采访录〉[An Interview with Han Dong], in《他们》7: 113-123 (excerpted in《诗探索》1996-3: 124129)

- \& Malingshu Xiongdi 马铃薯兄弟. 2004: 〈访问韩东〉 [An Interview with Han Dong], in 《中国诗人》2004-1: 98-103

\& Yang Li 杨黎. 2004: 〈韩东访谈〉 [An Interview with Han Dong], in Yang Li 2004: 284-311

\& Z Zhu Wen 朱文. 1993: 〈古闸笔谈〉 [Brushtalk at the Old Sluice], in 《作 家》1993-4: 68-73 
Hanne, Michael (ed). 2004: Creativity in Exile, Amsterdam etc: Rodopi

Hartman, Charles. 1986: "Poetry," in William H Nienhauser Jr with Charles Hartman, Y W Ma, Stephen H West (eds), The Indiana Companion to Traditional Chinese Literature, Bloomington: Indiana UP: 59-74

Hawkes, David. 1985: "General Introduction," in The Songs of the South: An Ancient Anthology of Chinese Poems by Qu Yuan and Other Poets, translated by David Hawkes, revised edition, Harmondsworth etc: Penguin

2007: "The Poetry of Liu Hongbin," MCLC Resource Center $\rightarrow$ Publications (online, see also p475)

He Jingzhi 贺敬之. 1979: 《贺敬之诗选》 [Selected Poems by He Jingzhi], 济南: 山 东人民

$\mathrm{He} \mathrm{Yi}$ 贺奕. 1994: 〈九十年代的诗歌事故: 评长诗《0档案》〉 [An Accident in Poetry of the Nineties: A Review of the Long Poem «File 0»], in 《大家》1994-1: 59-65

He Yuhuai. 1992: Cycles of Repression and Relaxation: Politico-Literary Events in China 19761989, Bochum: Brockmeyer

Herman, Luc \& Vervaeck, Bart. 2001: Vertelduivels: handboek verhaalanalyse [Narradevils: A Handbook of Narratological Analysis], Nijmegen: Vantilt / VUB Press

Hirsch, Charlotte. 2007: "37०8-Erhöhte Temperatur": Selbstdarstellung und-reflektion einer neuen Generation am Beispiel der Bloggerin Yin Lichuan [“37ㅇ- A Slight Temperature": Self-Representation and Self-Reflection of a New Generation: A Case Study of Yin Lichuan, Bloggeress], MA thesis, Universität Hamburg

Hockx, Michel (ed). 1999: The Literary Field of Twentieth-Century China, Richmond: Curzon

2000: "Liu Bannong and the Forms of New Poetry," in Fournal of Modern Literature in Chinese 3-2: 83-117

2003: Questions of Style: Literary Societies and Literary Fournals in Modern China, 1911-1937, Leiden etc: Brill

_ 2004: "Links With the Past: Mainland China's Online Literary Communities and Their Antecedents," in Fournal of Contemporary China, 13-38: 105-127

2005: "Virtual Chinese Literature: A Comparative Case Study of Online Poetry Communities," in The China Quarterly 183: 670-691

Hoffmann, Hans Peter. 1993: Gu Cheng: eine dekonstruktive Studie zur Menglong-Lyrik [Gu Cheng: A Deconstructive Study of Menglong Poetry], vols I-II, Frankfurt am Main etc: Peter Lang

Holton, Brian. 1994: “Translator's Afterword," in Yang Lian 1994b: 119-127

1999: "Translating Yang Lian," in Yang Lian 1999: 173-191

Hong. 1998: Hong Zicheng 洪子诚, 〈九十年代文学书系总序〉 [Literature of the Nineties, Foreword to the Series], in Cheng Guangwei 1998a: 1-9

2001: 《20世纪中国文学研究: 当代文学研究》 Research on $20^{\text {th }}$-Century Chinese Literature: The Contemporary Era], 北京: 北京

- (ed). 2002: 《在北大课堂读诗》 [Reading Poetry in the Classroom at Peking University], 武汉: 长江文艺

— \& Liu Denghan 刘登翰. 2005: 《中国当代新诗史》 [A History of China's Contemporary New Poetry], 北京: 北京大学 (revised edition; first edition 1993) \& Meng Fanhua 孟繁华 (eds). 2002: 《当代文学关键词》[Keywords in Contemporary Literature], 桂林: 广西师范大学

Hsu Kai-yu. 1975: The Chinese Literary Scene: A Writer's Visit to the People's Republic, New York: Vintage Books

Hu Shi. 1996: "Some Modest Proposals for the Reform of Literature," translated by Kirk A Denton, in Denton 1996: 123-139

Hu Tingwu 胡廷武. 2004:〈序〉 [Preface], in Yu Jian 2004a: 1-11 
$\mathrm{Hu}$ Xudong 胡续冬. 2005: 〈脱下隐身衣之后的诗歌: 2000 年以来 “诗歌生态” 的 一个侧面〉 [A Poetry That Sheds the Garb Which Makes It Invisible: A Profile of the “Poetry Ecology" since 2000], paper presented at 中国新诗: 百年国际研讨 会 (北京大学、首都师范大学举办), 18-20 August 2005

$\mathrm{Hu}$ Yan 胡彦. 1995: 〈于坚与诗的本质〉 [Yu Jian and the Essence of Poetry], in《诗探索》1995-2: 142-147

Huang Liang 黄粱. 1999: 〈文化与自然的本质对话: 纵论于坚诗篇的朴质理想〉 [An Essential Dialogue of Culture and Nature: A Broad Discussion of Yu Jian's Ideal of Simplicity], in 《当代作家评论》1999-4: 67-70 (originally the preface to Yu Jian 1999a)

Huang Lifang 黄黎方 (ed). 1994: 《朦胧诗人顾城之死》[The Death of Obscure Poet Gu Cheng], 广州: 花城

Huang Lihai 黄礼孩 (ed). 2001: 《’70后诗人诗选》 [Selected Poems by Post-70 Poets], 福州: 海风

Huang Xiang 黄翔. 2005: 〈流亡游戏: 质疑所谓 “反对派” 并对 “异议者” 持异议〉 [The Exile Game: Challenging the So-Called "Oppositionists" and Dissenting from the “Dissenters"], 博讯文坛 $\rightarrow$ 独立中文作家笔会 $\rightarrow$ 黄翔文集 (online, see also p475)

Huang Yibing. 2007a: Contemporary Chinese Literature: From the Cultural Revolution to the Future, New York: Palgrave Macmillan

2007b: "The Ghost Enters the City: Gu Cheng's Metamorphosis in the 'New World'," in Lupke 2007: 123-143 and 219-232

Huang Yunte. 2002: Transpacific Displacement: Ethnography, Translation, and Intertextual Travel in Twentieth-Century American Literature, Berkeley etc: University of California Press

Huanglin 荒林. 1998: 〈当代中国诗歌批评反思: “后新诗潮” 研讨会纪要〉 Reflections on Contemporary Chinese Poetry Criticism: A Report on the Seminar on "Post-New Tide Poetry"], in 《诗探索》1998-2: 73-82

Huot, Claire. 1999: "Here, There, Anywhere: Networking by Yong Chinese Writers Today," in Hockx 1999: 198-215

2000: China's New Cultural Scene: A Handbook of Changes, Durham etc: Duke UP

Idema, Wilt \& Grant, Beata. 2004: The Red Brush: Writing Women in Imperial China, Cambridge MA etc: Harvard UP

_ \& Haft, Lloyd. 1997: A Guide to Chinese Literature, Ann Arbor: Center for Chinese Studies, University of Michigan

Inwood, Heather. 2008: On the Scene of Contemporary Chinese Poetry, PhD thesis, School of Oriental \& African Studies, University of London

Jakobson, Roman. 1960: "Closing Statement: Poetics and Linguistics," in Thomas Sebeok (ed), Style in Language, Cambridge MA: MIT Press

Jameson, Fredric. 1991: Postmodernism, or, the Cultural Logic of Late Capitalism, London etc: Verso

Janssen, Ronald R. 2002: "What History Cannot Write: Bei Dao and Recent Chinese Poetry," in Critical Asian Studies 34-2: 259-277

Jenner, WJ F. 1990: review of Bei Dao 1988, in The Australian Fournal of Chinese Affairs 23: 193-195

Jiang Keping 江克平: see Crespi, John

Jiang Ruoshui 江弱水. 1997: 〈孤獨的舞蹈〉 [A Lonely Dance], in《傾向》10: 2130

Jiang Xi \& Wan Xiang 江熙、万象. 1995: 《灵魂之路: 顾城的一生》 $[\operatorname{Road}$ of the Soul: The Life of Gu Cheng], 北京: 中国人事 
Jiangjiang 江江. 1990:〈詩的放逐與放逐的詩〉 [The Banishment of Poetry and the Poetry of Banishment], in 《今天》1990-2: 68-75

Jin Han 金汉 (ed). 2002: 《中国当代文学发展史》 [A History of the Development of Contemporary Chinese Literature], 上海: 上海文艺

Jingbute 京不特. 1998: 〈從主流文化下的奴隸到一個獨立的個體人: 回憶八十年 代上海的地下文化〉 [From Slave to Mainstream Culture to Independent Individual Person: A Recollection of Shanghai Underground Culture in the Eighties], in 《傾向》11: 226-247

Jones, Andrew. 1994: "Chinese Literature in the "World' Literary Economy," in Modern Chinese Literature 8-1/2: 171-190

Kaldis, Nicholas. 2000: "The Prose Poem as Aesthetic Cognition: Lu Xun's Yecao," in Fournal of Modern Literature in Chinese 3-2: 43-82

Knight, Deirdre Sabina. 2003a: "Scar Literature and the Memory of Trauma," in Mostow et al 2003: 527-532

2003b: "Shanghai Cosmopolitan: Class, Gender and Cultural Citizenship in Weihui's Shanghai Babe," in Journal of Contemporary China 12-37: 639-653

Kong Shuyu. 2005: Consuming Literature: Best Sellers and the Commercialization of Literary Production in Contemporary China, Stanford: Stanford UP

Kramer, Oliver: see Krämer, Oliver

Krämer, Oliver. 1999: Oliver Krämer, "No Past to Long For? A Sociology of Chinese Writers in Exile," in Hockx 1999: 161-177

2002: Heinz Oliver Kramer (Oliver Krämer), Chinese Fiction Abroad: The Exilic Nature of Works Written by Chinese Writers Living Abroad after the Tiananmen Massacre, $\mathrm{PhD}$ thesis, University of Edinburgh

Krol, Gerrit. 1982: Het vrije vers [Free Verse], Amsterdam: Querido

Kubin, Wolfgang. 1993: "The End of the Prophet: Chinese Poetry between Modernity and Postmodernity," in Wendy Larson \& Anne Wedell-Wedellsborg (eds), Inside Out: Modernism and Postmodernism in Chinese Literary Culture, Aarhus: Aarhus UP: 1937

Lagos-Pope, María-Inés (ed). 1988: Exile in Literature, Lewisburg: Bucknell UP / London etc: Associated University Presses

Lan Dizhi 蓝棣之. 1994: 〈西川诗二首评点〉 [Comments on Two of Xi Chuan's Poems], in《诗探索》1994-2: 85-91

Lao $\mathrm{Mu}$ 老木 (ed). 1985a:《新诗潮诗集》[A Collection of New Tide Poetry], 共二 册, 北京: 北京大学五四文学社 (内部交流) (semi-official publication)

- (ed) 1985b:《青年诗人谈诗》[Young Poets on Poetry], 北京: 北京大学五 四文学社

Larson, Wendy. 1989: "Realism, Modernism and the Anti-'Spiritual Pollution' Campaign in China," in Modern China 15-1: 37-71

1999: "Never This Wild: Sexing the Cultural Revolution," in Modern China 25-4: 423-450

Lee, Gregory B (ed). 1993a: Chinese Writing and Exile, Chicago: The Center for East Asian Studies, University of Chicago

1993b: "Contemporary Chinese Poetry, Exile and the Potential of Modernism," in Lee (Gregory) 1993a: 55-77 (revised as Lee [Gregory] 1996: ch 5)

1996: Troubadours, Trumpeters, Troubled Makers: Lyricism, Nationalism, and Hybridity in China and Its Others, London: Hurst

Lee, Leo Ou-fan. 1973: The Romantic Generation of Modern Chinese Writers, Cambridge MA etc: Harvard UP 
1991: "On the Margins of the Chinese Discourse: Some Personal Thoughts on the Cultural Meaning of the Periphery," in Dedalus 120-2: 207-226 (reprinted in Lee [Gregory] 1993a: 1-18, and in Tu 1994: 221-238)

1995: Li Ou-fan 李欧凡, 〈既亲又疏的距离感〉 [An Intimate Yet Strange Sense of Distance], in Bei Dao 1995: 9-22

Lee, Mabel. 1990: "Introduction: The Philosophy of the Self and Yang Lian," in Yang Lian, Masks and Crocodile: A Contemporary Chinese Poet and His Poetry, translated by Lee, Sydney: University of Sydney East Asian Series: 9-36

1993: "Before Tradition: The Book of Changes and Yang Lian's $\$$ and the Affirmation of the Self Through Poetry," in Lee \& A D Syrokomla-Stefanowska (eds), Modernization of the Chinese Past, Sydney: Wild Peony, 1993: 94-106

Levie, Sophie. 2004: "Biografisme: een nieuwe plaats voor de auteur in de literatuurwetenschap?" [Biographism: A New Place for the Author in Literary Studies?], in Jaarboek van de Maatschappï der Nederlandse Letterkunde te Leiden, 2002-2003 [Yearbook of the Society of Dutch Literary Studies, 2002-2003], Leiden: Maatschappij der Nederlandse Letterkunde: 43-60

Leys, Simon. 1978: "Introduction," in Chen Jo-hsi, The Execution of Mayor Yin and Other Stories from the Great Proletarian Cultural Revolution, Bloomington etc: Indiana UP

Li Chao 李超. 1999: 〈形而上死〉 [Metaphysical Death], in Cui 1999a: 54-61 (dated 1992)

Li Dian. 2006: The Chinese Poetry of Bei Dao, 1978-2000: Resistance and Exile, Lewiston etc: Edwin Mellen Press

2007: "Naming and Anti-Naming: Poetic Debates in Contemporary China," in Lupke 2007: 185-200 and 219-232

Li Fukang \& Hung, Eva. 1992: "Post-Misty Poetry," in Renditions 37: 92-148

$\mathrm{Li} \mathrm{Ji}$ 李季. 1982: 《李季文集》[Collected Works of Li Ji], 共三册, 上海：上海文艺

Li Lizhong et al (eds). 1990: Li Lizhong, Zhang Lei \& Zhang Xu 李丽中、张雷、 张旭，《朦胧诗后：中国先锋诗选》 [After Obscure Poetry: Selected Chinese Avant-Garde Poems], 天津: 南开大学

$\mathrm{Li} \mathrm{Ou}$-fan 李欧凡: see Lee, Leo Ou-fan

Li Runxia 李润霞. 2004: 〈从历史深处走来的诗兽: 论黄翔在文革时期的地下 诗歌创作〉 [Poetry Beast Come Forth from the Depths of History: On Huang Xiang's Underground Poetry Writing during the Cultural Revolution], in 《蓝》2004-1: 133-147

2008: (李潤霞)《亂世潛流: 文化大革命時期的地下詩歌研究》 Undercurrent in a World in Turmoil: A Study of Underground Poetry during the Cultural Revolution], 台北: 台灣秀威, forthcoming

Li Shaojun 李少君. 1998: 〈现时性: 九十年代诗歌写作中的一种倾向〉 [Contemporeality: A Trend in Poetry Writing of the Nineties], in 《山花》1998-5: 82-86, 9

Li Xia (ed). 1999: Essays, Interviewes, Recollections and Unpublished Material of Gu Cheng, Twentieth-Century Chinese Poet: The Poetics of Death, Lewiston etc: Edwin Mellen Press

Li Xinyu 李新宇. 2000: 《中国当代诗歌艺术演变史》[An Evolutionary History of the Art of Contemporary Chinese Poetry], 杭州: 浙江大学

Li Yawei 李亚伟. 2006: 《豪猪的诗篇》 [Porcupine Poetry Writings], 广州: 花城

Li Zhen 李震. 1994: 〈神话写作与反神话写作〉 [Mythical Writing and Anti-Mythical Writing], in 《诗探索》1994-2: 4-17

1995:〈伊沙: 边缘或开端一神话 / 反神话写作的一个案例〉 [YiSha: Margins or Beginnings - A Case Study of Mythical / Anti-Mythical Writing], in 《诗 探索》1995-3: 90-99

- 2001a:《母语诗学纲要》[Mother-Tongue Poetics: An Outline], 西安: 三秦 $2001 \mathrm{~b}$ :〈先锋诗歌的前因后果与我的立场〉 [The Ramifications of Avant- 
Garde Poetry and My Standpoint], in Yang Ke 杨克 (ed), 《2000中国新诗年 鉴》 [2000 Yearbook of China's New Poetry], 广州: 广州: 596-604

Liao Yiwu 廖亦武 (ed). 1999:《沉沦的圣殿: 中国二十世纪70年代地下诗歌遗 照》 [Sunken Temple: China's Underground Poetry in the 70s of the Twentieth Century, a Portrait of Things Gone By], 乌鲁木齐: 新疆青少年

Liaoyuan 燎原. 1991: 〈孪生的麦地之子〉 [Twin Sons of the Wheatfields], in Haizi \& Luo 1991: 347-355 (dated 1989)

2001: 《扑向太阳之豹: 海子评传》 Leopard Pouncing at the Sun: A Critical Biography of Haizi], 海口: 南海

Lin Kehuan 林克歡. 1995: 〈成熟的生命與冰冷的世界〉 [Mature Life and an IceCold World], in 《現代詩》23: 20-21

Lin Xingqian 林幸謙. 2001: 〈當代中國流亡詩人與詩的流亡: 海外流放詩體的一 種閱讀〉[Contemporary China's Exile Poets and Poetry's Exile: Reading a Style of Poetry Banished Overseas], in 《中外文學》30-1: 33-64

Lin Yiliang 林以亮. 1976: 《林以亮詩話》 [Lin Yiliang's Poetry Talk], 台北: 洪範

Link, Perry. 1993: "Ideology and Theory in the Study of Modern Chinese Literature," in Modern China 19-1: 4-12

2000: The Uses of Literature: Life in the Socialist Chinese Literary System, Princeton: Princeton UP

2002: "The Anaconda in the Chandelier," in The New York Review of Books, 11 April 2002: 67-70

Liu Binyan \& Link, Perry. 1998: “A Great Leap Backward?”, review of He Qinglian 何清漣, 《中國的陷阱》[China's Pitfall], in The New York Review of Books, 8 October 1998: 19-22

Liu Fuchun 刘福春. 2004: 《新诗纪事》 [A Chronicle of New Poetry], 北京: 学苑

Liu He 劉禾 (ed). 2001: 《持燈的使者》[The Lamp-Bearing Messenger], 香港 etc: Oxford UP

Liu, James J Y. 1975: Chinese Theories of Literature, Chicago etc: University of Chicago Press

Liu, Melinda. 2004: “The Avant-Garde Art Goes Too Far?", in China Daily, 2 August 2004 (online, see also p475)

Liu Na 刘纳. 1994: 〈西川诗存在的意义〉 [The Significance of the Existence of Xi Chuan's Poetry], in 《诗探索》1994-2: 75-84

Liu Shijie 刘士杰. 1999: 《走向边缘的诗神》[The God of Poetry, Moving toward the Margins], 太原: 山西教育

Liu Shuyuan 刘树元 (ed). 2005: 《中国现当代诗歌赏析》 [Appreciations of Modern and Contemporary Chinese Poetry], 杭州: 浙江大学

Liu Tao Tao. 2001: "Exile, Homesickness and Displacement in Modern Chinese Literature," in Wolfgang Kubin (ed), Symbols of Anguish: In Search of Melancholy in China, Bern: Peter Lang: 335-351

Lovell, Julia. 2002: "Misty in Roots: Chinese Poetry after Mao," in Poetry Review 92-3: 64-68

2006: The Politics of Cultural Capital: China's Quest for a Nobel Prize in Literature, Honolulu: Hawai'i UP

Lu Jie. 2004: "Rewriting Beijing: A Spectacular City in Qiu Huadong's Urban Fiction," in Fournal of Contemporary China 13-39: 323-338

Lu Xun. 1996: "On the Power of Mara Poetry," translated by Shu-ying Tsau and Donald Holoch, in Denton 1996: 96-109

Lü Zhouju 吕周聚. 2001: 《中国当代先锋诗歌研究》[A Study of Contemporary Chinese Avant-Garde Poetry], 北京: 中国广播电视

Luo Gaolin 罗高林. 1996:《邓小平》 [Deng Xiaoping], 北京: 作家 
Luo Yihe 骆一禾. 1990: 〈“我考虑真正的史诗”〉 [“I Contemplate the True Epic”], in Haizi 1990: 1-10 (dated 1989) 1997a:〈海子生涯〉[Haizi’s Career], in Haizi 1997: 1-5 (dated 1989) 1997b: 《骆一禾诗全编》 [The Complete Poems of Luo Yihe], edited by Zhang $\mathrm{Fu}$ 张玞, 上海: 上海三连

Luo Zhenya 罗振亚. 2002: 《中国现代主义诗歌史论》 [On the History of Chinese Modernist Poetry], 北京: 社会科学文献

- 2005: 《朦胧诗后先锋诗歌研究》 [A Study of the Avant-Garde after Obscure Poetry], 北京: 中国社会科学

Lupke, Chris (ed). 2007: New Perspectives on Contemporary Chinese Poetry, New York: Palgrave MacMillan

Lyne, Sandra. 2002: "Consuming Madame Chrysanthème: Loti's 'Dolls' to Shanghai Baby," in Intersections: Gender, History \& Culture in the Asian Context 8 (online, see also p475)

Ma Ce 马策. 2001: 〈诗歌之死: 主要是对狂奔在 “牛B” 路上的 “下半身” 诗歌 团体的必要警惕〉 [The Death of Poetry: First of All, on the Need to Guard against the "Lower Body" Poetry Group Running Wild on a "Crash-Hot" Road], in《芙蓉》2001-2: 141-145

Maas, Michel. 1995: "Een postpostduistere dichter over de grenzen" [A Post-PostObscure Poet Crossing Borders], in De Volkskrant, 22 June 1995

MacLeish, Archibald. 1985: Collected Poems, 1917-1982, Boston: Houghton Mifflin

Mai Tong \& Xiaomin 麦童、晓敏. 1994: 《利斧下的童话》[A Fairy Tale under the Axe], 上海: 上海三联

Mallarmé, Stéphane. 1935: Vers et prose: morceaux choisis [Verse and Prose: Selected Pieces], Paris: Librairie Académique Perrin

Malmqvist, Göran. 1983: "On the Emergence of Modernistic Poetry in China," in Museum of Far Eastern Antiquities, Bulletin 55: 57-69

Mang Ke 芒克. 1988: 《阳光中的向日葵》 [Sunflower in the Sun], 桂林: 漓江 2003: 《燋! 这些人》 [Look at Them All!], 长春: 时代文艺

MaoJian 冒键. 2005: 《最后的神话: 诗人自杀之谜》 [The Last Myth: The Riddle of the Poet's Suicide], 银川: 宁夏人民

Mao Tse-tung. 1967: Selected Works of Mao Tse-tung, vols I-V, Beijing: Foreign Languages Press

Martin, Helmut. 1973: "A Transitional Concept of Chinese Literature 1897-1917: Liang Ch'i-ch'ao on Poetry-Reform, Historical Drama and the Political Novel," in Oriens Extremus 20-2: 175-217

McDougall, Bonnie S. 1980: Mao Zedong's 'Talks at the Tan'an Conference on Literature and Art": A Translation of the 1943 Text with Commentary, Ann Arbor: University of Michigan, Center for Chinese Studies

1985: "Bei Dao's poetry: Revelation \& Communication," in Modern Chinese Literature 1-2: 225-252

1993: "Censorship \& Self-Censorship in Contemporary Chinese Literature," in Susan Whitfield (ed): After The Event: Human Rights and Their Future in China, London: Wellsweep: 73-90 2003: Fictional Authors, Imaginary Audiences: Modern Chinese Literature in the Twentieth Century, Hong Kong: The Chinese University Press

— \& Louie, Kam. 1997: The Literature of China in the Twentieth Century, London: Hurst

Meng Lang 孟浪. 2005: 〈必要的丧失: 一九八九后的中国流亡文学〉 [Necessary Loss: Chinese Exile Literature since 1989], 博讯文坛 $\rightarrow$ 独立中文作家笔会 $\rightarrow$ 孟浪作品选编 (online, see also p475) 
Mi Jiayan. 2007: "Poetics of Navigation: River Lyricism, Epic Consciousness and the Post-Mao Sublime Poemscape," in Modern Chinese Literature \& Culture 19-1: 91-137

Mian Mian 棉棉. 2000: 《糖》[Candy], 北京: 中国戏剧

Michaud, Guy. 1953: Mallarmé: L'homme et l'œuvre [Mallarmé: The Man and the Works], Paris: Hatier-Bovin

Morewedge, Rosemarie T. 1988: "Exile in Heinrich Boell's Novel: Billiards at Half Past Nine," in Lagos-Pope 1988: 102-120

Morin, Edward (ed). 1990: The Red Azalea: Chinese Poetry since the Cultural Revolution, translated by Fang Dai, Dennis Ding \& Edward Morin, Honolulu: University of Hawai'i Press

Mostow et al (eds). 2003: Joshua Mostow with Kirk A Denton, Bruce Fulton \& Sharalyn Orbaugh: The Columbia Companion to Modern East Asian Literature, New York: Columbia UP

Nijhoff, Martinus. 1978: Verzamelde gedichten [Collected Poems], Amsterdam: Bert Bakker

Oosterhoff, Tonnus. 2006: "Wat er staat als er niets staat" [What It Says When It Says Nothing], review of Yra van Dijk, Leegte, leegte die ademt: Het typografisch wit in de moderne poëzie [Emptiness, Emptiness That Breathes: Typographical White in Modern Poetry], in NRC Handelsblad, 27 October 2006: 27

Ouyang Jianghe 欧阳江河. 1993a: (歐陽江河)〈89 後國內詩歌寫作: 本土氣質, 中年特徵與知識份子身份〉 [Writing Poetry inside China after '89: Indigenous Disposition, the Marks of Middle Age and Being an Intellectual], in 《今天》 1993-3: 176-198 (reprinted in domestic publications such as Wang Jiaxin \& Sun 2000: 181-200 and Chen Chao 2003: 165-185)

1993b: (歐陽江河) 〈另一種閱讀〉 [Another Kind of Reading], in《今 天》1993-4: 228-238

1996a: (歐陽江河)〈初醒時的孤獨: 序《零度以上的風景》〉[Awaken to Loneliness: Preface to Landscape over Zero], in Bei Dao 北島, 《零度以上的風景: 北島 1993-1996》 [Landscape over Zero: Bei Dao, 1993-1996], 台北: 九歌, 1996: 7-35 (reprinted as 〈北岛诗的三种读法〉 [Three Ways of Reading Bei Dao's Poetry] in Ouyang 欧阳, 《站在虚构这边》 [Side with the Fictitious], 北京: 三 联, 2001: 187-210

- 1996b: (歐陽江河)〈當代詩歌的昇華及其限制〉[Contemporary Poetry's Sublimation and Its Limitations], in 《今天》1996-3: 157-170

- 1997: 《谁去谁留》[Who Leaves and Who Stays], 长沙: 湖南文艺

Oversteegen, J J. 1983: "Analyse en oordeel" [Analysis and Assessment], in Oversteegen, De Novembristen van Merlyn: een literatuuropvatting in theorie en praktijk [The Novembrists of Merlyn: A View of Literature in Theory and Practice], Utrecht: HES: 15-71 (first published 1965)

Owen, Stephen. 1979: "Transparencies: Reading the T'ang Lyric," in The Harvard Fournal of Asiatic Studies 39-2: 231-251

1990: "What Is World Poetry? The Anxiety of Global Influence," in The New Republic, 19 November 1990: 28-32

1992: Readings in Chinese Literary Thought, Cambridge MA etc: Harvard UP 2003: "Stepping Forward and Back: Issues and Possibilities for 'World' Poetry," in Modern Philology 100-4: 532-548

Patton, Simon. 1994: A Poetics of Wubuwei: Two Texts by Gu Cheng, PhD thesis, University of Melbourne 
1995a: review of Bei Dao 1994, in Modern Chinese Literature 9-1: 139-145

1995b: review of Yang Lian 1994b, in World Literature Today 69-4: 871

1998: "Raindrops and Bottle Tops: An Introduction to Chinese Poetry in the 1990s," paper presented at the Chinese University of Hong Kong, 10 November 1998

2003a: "On Yu Jian's «Afternoon A Colleague Walking in Shadow»," in Cipher Fournal (online, see also p475)

2003b: "Yu Jian," Poetry International Web $\rightarrow$ China (online, date provided by Poetry International secretariat; see also p475)

2006: "Han Dong," Poetry International Web $\rightarrow$ China (online, date provided by Poetry International secretariat; see also p475)

Perelman, Bob. 1996: The Marginalization of Poetry: Language Writing and Literary History, Princeton: Princeton UP

Perloff, Marjorie. 1996: The Dance of the Intellect: Studies in the Poetry of the Pound Tradition, Evanston: Northwestern UP (first edition 1985)

1999: The Poetics of Indeterminacy: Rimbaud to Cage, Evanston: Northwestern UP, (first edition 1981)

Poe, Edgar Allan. 1973: The Portable Poe, edited by Philip Van Doren Stern, New York: Penguin

Pollard, D E. 1985: "The Controversy over Modernism 1979-1984," in The China Quarterly 104: 641-656

Porter, Peter. 2007: "Introduction: A Day within Days by Liu Hongbin," MCLC Resource Center $\rightarrow$ Publications (online, see also p475)

Preminger, Alex (ed). 1965: Encyclopedia of Poetry and Poetics, Princeton: Princeton UP

Qin Bazi 秦巴子. 1999:〈海子批判: 史诗神话的破灭〉 [Criticizing Haizi: Shattering the Myth of the Epic], in Yi et al 2001: 225-252.

Renminwang 人民網. 2006: 〈十年間從人們嘴邊消失的49個老詞〉 [Forty-Nine Old Words That Have Disappeared from People's Lips in the Last Ten Years], 人民網 $\rightarrow$ 文化 $\rightarrow$ 新聞, 15 September 2006 (online, see also p475)

Robb, Graham. 2000: Rimbaud, London etc: Picador

Safran, William. 1991: "Diasporas in Modern Societies: Myths of Homeland and Return," in Diaspora 1-1: 83-99

Said, Edward W. 1984: "The Mind of Winter: Reflections on Life in Exile," in Harper's 269: 49-55

2001: "Reflections on Exile," in Said, Reflections on Exile and Other Literary and Cultural Essays, London: Granta Books: 173-186 (revised and expanded edition of Said 1984)

Saussy, Haun. 1999: "Bei Dao and his Audiences," Stanford Presidential Lectures in the Humanities and Arts (online, see also p475)

Schneider, Laurence A. 1980: A Madman of Ch'u: The Chinese Myth of Loyalty and Dissent, Berkeley etc: The University of California Press

Shang Zhongmin 尚仲敏. 1988: 〈反对现代派〉 [Against the Modernists], in Wu Sijing 1993: 228-235

Shanghai Literature \& Art Press 上海文艺出版社 (ed). 1986: 《探索诗集》[A Collection of Explorative Poems], 上海: 上海文艺

Shen Haobo 沈浩波. 1999: 〈后口语写作在当下的可能性〉 [The Possibilities of Post-Colloquial Writing in the Here-and-Now], in 《诗探索》1999-4: 34-42

— 2001a: 《一把好乳》 [A Handful of Tit], 北京 (unofficial publication)

2001b: 《我要先锋到死! 在 “中国南岳九十年代汉语诗歌研究论坛”上的 
发言〉 [Avant-Garde unto Death! Speech at the "Nanyue Forum for the Study of Poetry of the Nineties in Chinese"], in 《原创性写作》2: 30-34

- 2002: 〈下半身阿下半身〉 [Lower Body Oh Lower Body], in 《蓝》6: 98101

2004: 《心藏大恶》 [Great Evil Hidden in the Heart], 大连: 大连

\& Yin Lichuan 沈浩波、尹丽川. 2001:〈实话实说 “下半身”〉 [Straight Talk on the "Lower Body"], in 《诗江湖》1: 69-73

Shen Qi 沈奇 (comp). 1995: 〈对《0档案》发言〉 [Statements on «File 0»], in《诗 探索》1995-2: 155-156

- 1996: 《詩是什麼: 20世紀中國詩人如是說 (當代大陸卷)》[What Is Poetry: Views of $20^{\text {th }}$-Century Chinese Poets (Contemporary Mainland Volume)], 台北: 爾雅

Shi Jile 释极乐 (ed). 1982: 《次生林》 [Born-Again Forest], 成都 (unofficial publication; pseudonym of Zhong Ming)

Shikan she 诗刊社. 1998: 〈中国诗歌现状调查〉 [nvestigation into the Current State of Chinese Poetry], in 《诗刊》1998-9: 4-8

Shizhi 食指. 2006:《食指》[Shizhi], 北京: 人民文学

Shu Ting 舒婷. 1982: 《双桅船》[Two-Master], 上海: 上海文艺

Simon, John. 1965: "Prose Poem," in Preminger 1965: 664-666

1987: The Prose Poem as a Genre in Nineteenth-Century European Literature, New York etc: Garland

Song Lin 宋琳. 2002: 〈主導的迴圈: 《空白練習曲》序〉 [Dominant Cycles: Preface to Blank Études], in Zhang Zao \& Song 2002: xv-xxvi

Song Xiaoxian 宋晓贤. 1999: 〈中国诗坛的可悲现状〉 [The Sorry State of the Chinese Poetry Scene], in 《诗参考》1999: 98-99

Song Yongyi 宋永毅. 1997: 〈文革中的黄皮書和灰皮書〉 [Yellow Books and Grey Books in the Cultural Revolution], in 《二十一世紀》42: 59-64

_ 2007: "A Glance at the Underground Reading Movement during the Cultural Revolution," in Fournal of Contemporary China 16-51: 325-333

Song Zuifa 宋醉发 (ed, phot). 2008: 《中国诗歌的脸》[The Face of Chinese Poetry], 香港: 中国文化

Soong, Stephen C \& Minford, John (eds). 1984: Trees on the Mountain: An Anthology of New Chinese Writing, Hong Kong: The Chinese University Press

Sötemann, A L. 1985: "Vier poetica's" [Four Poetics], in W J van den Akker \& G J Dorleijn (eds), A L Sötemann, Over poetica en poëzie [On Poetics and Poetry], Groningen: Wolters-Noordhoff: 119-130

Spalek, John M \& Bell, Robert F (eds). 1982: Exile: The Writer's Experience, Chapel Hill: University of North Carolina Press

Su Wei \& Larson, Wendy. 1995: "The Disintegration of the Poetic 'Berlin Wall'," in Deborah S Davis, Richard Kraus, Barry Naughton \& Elizabeth J Perry, Urban Spaces in Contemporary China: The Potential for Autonomy and Community in PostMao China, Washington etc: The Woodrow Wilson Center Press / Cambridge: Cambridge UP: 279-293

Suleiman, Susan Rubin (ed). 1998: Exile and Creativity: Signposts, Travelers, Outsiders, Backward Glances, Durham etc: Duke UP (first published as Poetics Today 17-3/4 [1996])

Sun Wenbo 孙文波. 1997: 《地图上的旅行: 孙文波诗选》 Journey on the Map: Selected Poems by Sun Wenbo], 北京: 改革

1998b: 〈我的诗歌观〉 [My Poetics], in 《诗探索》1998-3: 148-156 2001a: 《孙文波的诗》 [The Poetry of Sun Wenbo], 北京: 人民文学 2001b: 〈我怎麼成为了自己〉 [How I Became Myself], unpublished manuscript 
Tabori, Paul. 1972: The Anatomy of Exile: A Semantic and Historical Study, London: Harrap

Tan Chee-Lay. 2007: Constructing a System of Irregularities: The Poetry of Bei Dao, Yang Lian and Duoduo, $\mathrm{PhD}$ thesis, University of Cambridge

Tan Wuchang 谭五昌. 1999:〈海子论〉 [On Haizi], in Cui 1999a: 187-214

Tang Chao \& Robinson, Lee (eds \& transl). 1992: New Tide: Contemporary Chinese Poetry, Toronto: Mangajin Books

Tang Xiaobing. 2000: Chinese Modern: The Heroic and the Quotidian, Durham etc: Duke UP

Tang Xiaodu (ed). 1992: 《灯芯线幸福的舞蹈: 后朦胧诗萃》 [The Happy Dance of Corduroy: Selected Post-Obscure Poems], 北京: 北京师范大学

1999: 〈90 年代先锋诗的若干问题〉 [Some Issues in Avant-Garde Poetry of the 90s], in Tang 唐 (ed), 《先锋诗歌》[Avant-Garde Poetry], 北京: 北京师 范大学: 1-19 (abridged; the full text is included in Tang 唐, 《唐晓渡诗学论 集》 [Tang Xiaodu's Essays in Poetics], 北京: 中国社会科学, 2001: 104-123) - 2006: “终于被大海摸到了内部”: 从大海意象看杨炼漂泊中的写作〉

["Finally Touched on the Inside by the Sea": The Image of the Sea as a Perspective on Yang Lian's Wandering Writing], in 《新诗评论》2006-2: 111-138 (also available from Yang Lian's website $\rightarrow$ 中文 $\rightarrow$ 评论研究)

— \& Wang Jiaxin 王家新 (eds). 1987: 《中国当代实验诗选》 [Selected Contemporary Experimental Chinese Poems], 沈阳: 春风文艺

Tang Xin 唐欣. 2000: 〈写作何必 “知识分子”〉 [Why Should Writing Be “Intellectual”], in 《诗参考》2000: 68-69

Tao Naikan. 2006: "Introduction: The Changing Self," in Tao \& Prince 2006: 3-26 \& Prince, Tony (eds \& transl). 2006: Eight Contemporary Chinese Poets, Sydney: Wild Peony

Teeuwen, Rudolphus. 2004: "Fading into Metaphor: Globalization and the Disappearance of Exile," in Hanne 2004: 283-298

Teng, Emma J. 2005: "What's 'Chinese' in Chinese Diasporic Literature?”, in Charles Laughlin (ed), Contested Modernities in Chinese Literature, New York etc: Palgrave MacMillan: 61-79

Them Literature Web. 《他们文学网》(online, see also p475)

Tian Zhiwei 田志伟. 1987: 《朦胧诗纵横谈》 [A Free and Easy Discussion of Obscure Poetry], 沈阳: 辽宁大学

Tong Ziguang \& Chen Rongbin 佟自光、陈荣斌 (eds). 2004: 《人一生要读的60首 诗歌》 [60 Poems One Must Read in This Life], 北京: 中国书籍

Tu Wei-ming. 1991: "Cultural China: The Periphery as the Center," in Dedalus 120-2: 1-32 (reprinted in Tu 1994: 1-34, 261-268)

- (ed) 1994: The Living Tree: The Changing Meaning of Being Chinese Today, Stanford: Stanford UP

Twitchell-Waas, Jeffrey. 2005: "Dazzling Songs Hanging in the Void: Yang Lian's \$," in Chicago Review 50-2/3/4: 334-345

\& Huang Fan. 1997: "Avant-Garde Poetry in China: The Nanjing Scene, 1981-1992," in World Literature Today 71-1: 29-38

Van Crevel, Maghiel. 1996: Language Shattered: Contemporary Chinese Poetry and Duoduo, Leiden: CNWS

2000: Poëzie in tïden van geest, geweeld en geld [Poetry in Times of Mind, Mayhem and Money], Leiden: CNWS

2001: “Translator's Introduction [to Yu Jian's «File 0»]," in Renditions 56: $19-23$

2003a: "Zhai Yongming," in Lily Lee (ed), Biographical Dictionary of Chinese Women: The Twentieth Century, 1912-2000, Armonk, NY: M E Sharpe: 672-678 
2003b: "The Horror of Being Ignored and the Pleasure of Being Left Alone: Notes on the Chinese Poetry Scene," MCLC Resource Center $\rightarrow$ Publications (online, see also p475)

2003c: "The Poetry of Yan Jun," MCLC Resource Center $\rightarrow$ Publications (online, see also p475)

-2004: "Who Needs Form? Wen Yiduo's Poetics and Post-Mao Poetry," in Peter Hoffmann (ed), Poet, Scholar, Patriot: In Honour of Wen Kiduo's $100^{\text {th }}$ Anniversary, Bochum etc: Projektverlag: 81-110

2005: "Yan Jun," DACHS poetry chapter $\rightarrow$ Yan Jun (online, see also $\mathrm{p} 475)$

2007: "Unofficial Poetry Journals from the People's Republic of China: A Research Note and an Annotated Bibliography," MCLC Resource Center $\rightarrow$ Publications (online, see also p475)

2008a: "Avant-Garde Poetry from the People's Republic of China: A Bibliography of Single-Author and Multiple-Author Collections," MCLC Resource Center $\rightarrow$ Publications (online, see also p475)

2008b: "Avant-Garde Poetry from the People's Republic of China: A Bibliography of Scholarly and Critical Books in Chinese," MCLC Resource Center $\rightarrow$ Publications (online, see also p475)

\& Van Toorn, Willem. 1990: "Een innerlijke culturele revolutie: een gesprek met Bei Dao en Duoduo" [An Inner Cultural Revolution: A Conversation with Bei Dao and Duoduo], in Raster 50: 124-127

Visser, Robin. 2002: "Privacy and Its Ill Effects in Post-Mao Urban Fiction," in Bonnie McDougall \& Anders Hansson (eds), Chinese Concepts of Privacy, Leiden etc: Brill: 171-194

Wan Xia \& Xiaoxiao 万夏、潚潇 (eds). 1993: 《后朦胧诗全集: 中国现代诗编年 史》 [The Complete Post-Obscure Poetry: Annals of Modern Chinese Poetry], 共二册, 成都: 四川教育

Wan Zhi 萬之 (ed). 1997a: 《溝通: 面對世界的中國文學》[Breaking the Barriers: Chinese Literature Facing the World], Stockholm: Olof Palme International Center (English translation in Wan Zhi 1997b)

(ed) 1997b: Breaking the Barriers: Chinese Literature Facing the World, translated by Chen Maiping, Anna Gustafsson \& Simon Patton, Stockholm: Olof Palme International Center (Chinese translation of Wan 1997a)

Wang Ban. 1997: The Sublime Figure of History: Aesthetics and Politics in Twentieth-Century China, Stanford: Stanford UP

Wang Bin 王涁 (ed). 1991: 《二十世纪中国新诗鉴赏辞典》[A Critical Anthology of China's New Poetry of the Twentieth Century], 北京: 中国文联

(ed). 1998:《二十世纪中国新诗选》[A Selection of China's New Poetry of the Twentieth Century], 北京: 大众文艺

Wang, David Der-wei. 1994: "Afterword: Chinese Fiction for the Nineties," in Wang with Jeanne Tai (eds), Running Wild: New Chinese Writers, New York: Columbia UP: 238-258

2000: David Der-wei Wang, "Introduction," in Chi \& Wang 2000: xiii-xliii

2004: David Der-wei Wang, The Monster That Is History: History, Violence and Fictional Writing in Twentieth-Century China, Berkeley: University of California Press

Wang Guangdong 王光东. 2002:〈民间〉 [Popular], in Hong \& Meng 2002: 213-217

Wang Guangming 王光明. 1986:〈散文诗〉 [Prose Poetry], in《中国大百科全书: 
中国文学 II》 [The Great Chinese Encyclopedia: Chinese Literature II], 北京: 中国大百科全书: 687-688

1993: 《艰难的指向: “新诗潮” 与二十世纪中国现代诗》 [Pointing the

Way in Hardship: "New Tide Poetry" and Twentieth-Century Modern Chinese Poetry], 长春: 时代文艺

1999: 〈个体承担的诗歌〉 [Poetry Undertaken by the Individual], in《诗探

索》1999-2: 17-20, 25

2003: 《现代汉诗的百年演变》 [Modern Han Poetry: A Hundred Years of Evolution], 石家庄: 河北人民

Wang Guozhen 汪国真. 1991: 《汪国真爱情诗选》[Selected Love Poetry by Wang Guozhen], 北京: 中国友谊

Wang Jiaping 王家平. 2004《文化大革命时期诗歌研究》 [A Study of Poetry during the Cultural Revolution], 开封: 河南大学

Wang Jiaxin 王家新. 1993: Selected Poems by Wang Fiaxin, translated by John Cayley, London: Wellsweep (floppy disk containing written texts and audio recordings)

1994: 《谁在我们中间》[Who Is Among Us], in《诗探索》1994-4: 99103

1997: 《游动悬崖》[Moving Cliffs], 长沙: 湖南文艺

1999: 〈知识分子写作, 或包 ‘献给无限的少数人’ [Intellectual Writing, or

“In Dedication to a Limitless Minority”], in《诗探索》1999-2: 38-52 and 85

2001: 《王家新的诗》 [The Poetry of Wang Jiaxin], 北京: 人民文学

2002: 《没有英雄的诗: 王家新诗学论文随笔集》 [Poetry without Heroes:

Wang Jiaxin's Essays and Short Prose on Poetry], 北京: 中国社会科学

\& Chen Dongdong 陈东东 \& Huang Canran 黄灿然. 1993: 〈回答四十个 问题〉[Answers to Forty Questions], in 《南方诗志》1993 秋: $42-57$ (interview, unofficial publication, reprinted [abridged] in Wang Jiaxin 1997: 187-214)

\& Sun Wenbo 孙文波 (eds). 2000: 《中国诗歌: 九十年代备忘录》[Chinese Poetry: Memorandum for the Nineties], 北京: 人民文学

Wang Jifang 汪继芳 (ed). 2000:《断裂: 世纪末的文学事故一自由作家访谈录》 [Rupture: An Accident in Literature at the End of the Century-Interviews with Free Writers], 南京: 江苏文艺

Wang Jing. 1996: High Culture Fever: Politics, Aesthetics, and Ideology in Deng's China, Berkeley etc: University of California Press

Wang Ping (ed). 1999: New Generation: Poems from China Today, translated by Wang and various others, New York: Hanging Loose Press

Wang Yichuan 王一川. 1998:《中国形象诗学: 1985 至1995 年文学新潮阐释》 [Chinese Image Poetics: Interpretations of the New Tide in Literature from 1985 to 1995], 上海: 上海三联 1999a:〈在口语与杂语之间〉 [Between Colloquialism and Miscellanism], in《当代作家评论》1999-4: 43-51

1999b:〈海子: 诗人中的歌者〉[Haizi: Singer among Poets], in Cui 1999a: 245-259

Wang Yuechuan. 1999: "A Perspective on the Suicide of Chinese Poets in the 1990s," translated by Li Xia, in Li Xia 1999: 77-95

Wang Zheng \& Xiaohua 汪政、晓华. 1999: 〈词语物: 有关于坚写作的讨论〉 [Words and Things: A Discussion of Yu Jian's Writing], in 《当代作家评论》 1999-4: 50-57

Weber, Eugen. 1960: Paths to the Present: Aspects of European Thought from Romanticism to Existentialism, New York: Dodd, Mead and Company

Wei Tianwu 魏天无. 2006: 《新诗现代性追求的矛盾与演变: 九十年代诗论研 究》[Contradiction and Evolution in the New Poetry's Pursuit of Modernity: A Study of Poetics in the Nineties], 武汉: 湖北教育 
Wei'an 苇岸. 1994:〈怀念海子〉 [n Commemoration of Haizi], in《诗探索》19943: $98-108$

Weihui 卫慧. 1999: 《上海宝贝》[Shanghai Babe], 沈阳: 春风文艺

Wen Xin 文听. 1994: 《顾城绝命之谜: 英儿解秘》 [The Riddle of Gu Cheng on the Verge of Death: The Secret of Ying'er Divulged], 北京: 华艺

Wigman, Menno (ed \& transl). 1998: Wees altïd dronken! Franse prozagedichten uit het fin de siècle [Be Forever Drunk! French Prose Poems from the Fin de Siècle], Amsterdam: Voetnoot

Wong, Lawrence Wang-chi. 1993: "I Am a Prisoner in Exile': Wen Yiduo in the United States," in Lee (Gregory) 1993a: 19-34

Wong, Lisa Lai-ming. 2001: "Writing Allegory: Diasporic Consciousness as a Mode of Intervention in Yang Mu's Poetry of the 1970s," in Fournal of Modern Literature in Chinese 5-1: 1-28

Wu Jingrong \& Cheng Zhenqiu 吴景荣、程镇球 (eds). 2000: 《新时代汉语大词 典》 [New Age Chinese-English Dictionary], 北京: 商务

Wu Kaijin 吴开晋 (ed). 1991: 《新时期诗潮论》 [On the Rising Tide of Poetry in the New Era], 济南: 济南

Wu Sijing 吴思敬 (ed). 1993: 《磁场与魔方: 新潮诗论卷》 Magnetic Field and Magic Square: New Tide Poetry Criticism Volume], 北京: 北京师范大学 (in Xie Mian \& Tang 1993

- 1996:〈启蒙・失语 - 回归: 新时期诗歌理论发展的一道轨迹〉 [Enlightenment-Speechlessness - Homecoming: A Path of Development for Poetic Theory in the New Era], in 《诗刊》1996-7: 51-54

- 1997: 〈九十年代中国新诗走向摭谈〉 [Scattered Remarks on the Alignment of China's New Poetry in the Nineties], in 《文学评论》4: 79-85 2002: 《走向哲学的诗》 [Poetry Moving toward Philosophy], 北京: 学苑 2005: 〈中国新诗: 世纪初的观察〉 [China's New Poetry: Observations for the New Century], in 《文学评论》2005-5: 107-112

Wu Xiaodong \& Xie Linglan, 吴晓东、谢凌岗. 1991: 〈诗人之死〉 Death of the Poet], in Haizi \& Luo 1991: 356-360

Wu Xinhua 吴新化. 2004: 〈固守人类精神的高地: 对当代诗歌边缘化的思考〉 [Guard the Heights of the Human Spirit: Thoughts on the Marginalization of Contemporary Poetry], in《湖州师范学院学报》26-4: 15-18

Xi Chuan 西川. 1988: 〈艺术自释〉 [The Author's Explanation of His Art], in Xu Jingya et al 1988: 361-362 - 1991a:〈怀念〉 [Remembrance], in Haizi \& Luo 1991: 307-312 (dated 1990, on Haizi)

- 1991b: 〈怀念〉 [Remembrance], in Haizi \& Luo 1991: 313-318 (dated 1990, on Luo Yihe)

1994a: 〈死亡后记〉 [Afterword to Death], in《诗探索》1994-3: 88-97

1994b: 〈诗歌炼金术〉[The Alchemy of Poetry], in 《诗探索》1994-2:

$72-74$

61-66

- 1997a: 《虚构的家谱》[A Fictitious Genealogy], 北京: 中国和平

1997b: 《让蒙面人说话》[Let the Masked Speak], 上海: 东方

1997c: 《大意如此》 [This Is the Idea], 长沙: 湖南文艺

1997d: 《隐秘的汇合》[Secret Convergence], 北京: 改革

1997e: 〈在路上〉 [On the Road], in《作家》1997-4: 68-69

- 1999a: 《西川的诗》 [The Poetry of Xi Chuan], 北京: 人民文学 
1999b:〈鹰的话语〉 [What the Eagle Says]，in《第三届爱文文学奖颁奖

会》 [Award Ceremony for the Third Aiwen Award for Literature], 北京: 爱文文学

院, 14 February 1999 (reprinted in Zhang Zao \& Song 2002: 181-193) 2001: 《水渍》[Water Stains], 天津: 百花文艺

Xi Du 西渡. 2000: 《守望与倾听》[Stand Guard and Listen Close], 北京: 中央编译 Xi Mi 奚密: see Yeh, Michelle

Xi Yunshu 席云舒. 2001: 〈困顿中的反思: 关于世纪之交的诗坛现状及其局限〉

Reflections in the Midst of Fatigue: On the State of the Poetry Scene at the Turn of the Century, and Its Limitations], in 《诗探索》2001-3/4: 55-63

Xia Yuanming 夏元明. 2005: 〈回到隐喻之前: 于坚诗学与创作〉 [Return to before Metaphor: Yu Jian's Poetics and His Creative Writing], in《长江学术》7: 113119

Xiang Weiguo 向卫国. 2002: 《边缘的呐喊: 现代性汉诗诗人谱系学》 [Shouts from the Margins: A Genealogy of Poets of Modern Han Poetry], 北京: 作家

Xiao Hai 小海. 1998:〈诗到语言为止吗〉 [Poetry Goes No Farther Than Language?], in 《诗探索》1998-1: 19-21

Xiao Kaiyu 肖开愚. 1995: 〈生活的魅力〉 [The Charm of Life], in《诗探索》19952: $157-161$

— 1997a: 〈九十年代诗歌: 抱负, 特征和资料〉 [Poetry of the Nineties: Aspirations, Characteristics, Material], in 《学术思想评论》1997-1: 215-234

1997b: 〈当代中国诗歌的困惑〉 [Confusion in Contemporary Chinese Poetry], in《读书》1997-11: 90-97

- 2000: 《学习之甜》 [Sweetness of Learning] , 北京: 中国工人 2004: 《肖开愚的诗》 [The Poetry of Xiao Kaiyu], 北京: 人民文学

Xiao Quan 肖全. 2006: 《我们这一代》 [This Our Generation], 广州: 花城

Xiao Xialin 萧夏林 (ed). 1994: 《顾城弃城》 [Gu Cheng Abandons the City \{or: Gu Cheng Abandons Cheng\}], 北京: 团结

Xiao Ying 肖鹰. 1999: 〈向死亡存在〉 [Existence Leading toward Death], in Cui 1999a: 226-231

Xiaoxiao 萧萧. 1998: 〈台湾散文诗美学〉 [The Aesthetics of Taiwan Prose Poetry], in Xiandai Hanshi bainian yanbian ketizu 现代汉诗百年演变课题组 (ed), 《现代汉诗: 反思与求索》[Modern Han Poetry: Introspection and Exploration], 北京: 作家: 315-338

Xie Mian 谢冕. 1980:〈在新的崛起面前〉 [Facing the New Rising], in《光明日 报》, 7 May 1980

\& Meng Fanhua 孟繁华 (eds). 1996: 《中国百年文学经典文库1895-1995: 诗歌卷》 [Classics from the Treasure House of One Hundred Years of Chinese Literature, 1895-1995: Poetry Volume], 深圳: 海天

— \& Tang Xiaodu 唐晓渡 (eds). 1993: 《当代诗歌潮流回顾》 [A Review of Trends in Contemporary Poetry], 共六册, 北京: 北京师范大学

Xie Youshun 谢有顺. 1999: 〈回到事物与存在的现场: 于坚的诗与诗学〉 [Back to the True Site of Objects and Being: The Poetry and Poetics of Yu Jian], in 《当代 作家评论》1999-4: 58-66

- 2001: 〈文学身体学〉 [The Bodily Art of the Literary Art], in 《花城》2001-6: 193-205

Xin Yue 辛月. 1995: 〈于坚诗二首赏析〉 [Appreciations of Two Poems by Yu Jian], in《诗探索》1995-2: 148-154

Xiping 溪萍 (ed). 1988: 《第三代诗人探索诗选》[Selected Explorative Poems by Poets of the Third Generation], 北京: 中国文联

Xu Jiang 徐江. 1999a:〈玩弄中国诗歌〉[Playing Chinese Poetry], in 《文友》19992: 20-21 86-90 
2001: 〈从头再来-1999-2001：诗人的被缚与诗歌的内在抗争〉 [Start All Over Again - 1999-2001: The Poet's Bonds and Poetry's Internal War of Resistance], in 《芙蓉》2001-2: 130-135

Xu Jingya 徐敬亚 (ed). 1986:〈中国诗坛1986 现代诗群体大展〉 [Grand Exhibition of Modern Poetry Groups on China's Poetry Scene, 1986], in 《诗歌报》, 21 October 1986 and 《深圳青年报》, 21 and 24 October 1986

1989: 《崛起的诗群》[A Volant Tribe of Bards], 上海: 同济大学

- et al (eds). 1988: Xu Jingya, Meng Lang, Cao Changqing \& Lü Guipin 徐 敬亚、孟浪、曹长青、吕贵品, 《中国现代主义诗群大观 1986-1988》[Overview of Chinese Modernist Poetry Groups 1986-1988], 上海: 同济大学

Yan Jun 颜峻. 2001: 《次声波》 [Infrasonic Sound], 北京: 铁托出品 SUB JAM B (unofficial publication)

2005: Sub Fam 012 (CD-rom), 北京 (unofficial, also available at DACHS poetry chapter $\rightarrow$ Yan Jun, with an introduction by Maghiel van Crevel; online, see also p475)

2006a: "live at Beida poem....," Yan Jun's MySpace page (online, see also $\mathrm{p} 475)$

2006b: 《不可能》[Impossible], 北京(unofficial publication)

Yan Yuejun et al (eds). 1985: Yan Yuejun, Gao Yan, Liang Yun \& Gu Fang 阎月君、 高岩、梁云、顾芳，《朦胧诗选》[Selected Obscure Poems], 沈阳: 春风文艺

Yang Changzheng 杨长征. 1994:〈西川: 仰望星空的智者〉 [Xi Chuan: Wise Man Gazing at the Starry Sky], in 《北京青年》7: 47-48

Yang Jian 杨健. 1993: 《文化大革命中的地下文学》 [Underground Literature during the Cultural Revolution], 济南: 朝华

Yang Ke 杨克 (ed). 2000: 《1999 中国新诗年鉴》 [1999 Yearbook of China’s New Poetry], 广州: 广州

- \& Wen Yuanhui 温远辉. 1996:〈在一千种鸣声梳理诗的羽毛〉[Comb Out Poetry's Feathers from among a Thousand Bird Calls], in 《山花》9: 75-77

Yang Lan. 1998: Lan Yang, Chinese Fiction of the Cultural Revolution, Hong Kong: Hong Kong UP

Yang Li 杨黎. 2004: 《灿烂: 第三代的写作和生活》 [Splendor: The Writing and the Lives of the Third Generation], 西宁: 青海人民

Yang Lian 杨炼. 1980:《太阳每天都是新的》 [There Is a New Sun Every Day], 北 京 (unofficial publication) 1989a:《黄》[Yellow], 北京: 人民文学

1989b: 《人的自觉》[The Self-Awakening of the Human Being], 成都: 四 川人民

- 1990: Yang Lian, The Dead in Exile, bilingual, translated by Mabel Lee,

Canberra: Tiananmen

- 1991: 《太阳与人》 [The Sun and the Human Being], 长沙: 湖南文艺

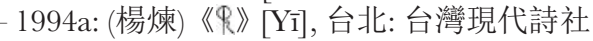

1994b: Non-Person Singular, bilingual, translated by Brian Holton, London:

Wellsweep

1996: "Living in the Now and Forever: A Way Forward for Chinese Lite-

rature," translated by Yang Lian \& John Cayley, in The Times Literary Supplement, 25 October 1996: 14

1998a: 《大海停止之处: 杨炼作品 1982-1997—诗歌卷》 [Where the Sea Stands Still: Works by Yang Lian, 1982-1997-Poetry Volume], 上海: 上海文 艺

1998b: 《鬼话. 智力的空间: 杨炼作品1982-1997一散文 - 文论卷》 [Ghost- 
speak - Intellectual Space: Works by Yang Lian, 1982-1997- Short Prose and Essays Volume], 上海: 上海文艺

1998c: "The Writer and the Party: Western Misunderstandings of Contemporary Chinese Literature," translated by Brian Holton, in The Times Literary Supplement, 6 November 1998: 18-19

1999: Where the Sea Stands Still, bilingual, translated by Brian Holton, Newcastle upon Tyne: Bloodaxe

2002a: Notes of a Blissful Ghost, translated by Brian Holton, Hong Kong:

Renditions

_ 2002b: $\Upsilon_{i} \$$, bilingual, translated by Mabel Lee, Los Angeles: Green Integer 2002c: "In Search of Poetry as the Prototype of Exile," translated by Torbjörn Lodén, in 00tal 9/10: 35-41 (for a Chinese edition, see Yang Lian's website or Yang 杨, 〈追寻作为流亡原型的诗〉 [In Search of Poetry as the Prototype of Exile], in Zheng et al 2005: 235-240) - 2003: 《幸福鬼魂手记: 杨炼作品1998-2002 一诗歌、散文、文论》 [Notes of a Blissful Ghost: Works by Yang Lian, 1998-2002-Poetry, Short Prose, Essays], 上海: 上海文艺

2006: Unreal City: A Chinese Poet in Auckland, edited and introduced by Jacob Edmond \& Hilary Chung, Auckland: Auckland UP

- website: Yang Lian (online, see also p475)

\& Yo Yo 友友. 1994: 《人景. 鬼话: 杨炼、友友海外漂泊手记》 [Peoplescapes - Ghostspeak: Notes by Yang Lian and Yo Yo on Wandering Overseas], 北京: 中央编译

Yang Lihua 杨立华. 2003: 〈北岛诗二首解读〉 [Two Poems by Bei Dao: An Interpretation], in《诗探索》2003-3/4: 173-183

Yang Siping 杨四平. 2004: 《20世纪中国新诗主流》[The Mainstream in China's New Poetry of the $20^{\text {th }}$ Century], 合肥: 安徽教育

Yang Xiaobin 杨小滨. 1994: 〈今天的 “今天派” 诗歌: 论北岛、多多、严力、杨 炼的海外诗作〉 [The Poetry of the "Today School" Today: On Overseas Poetry by Bei Dao, Duoduo, Yan Li and Yang Lian], in 《现代汉诗》15/16: 107-120 (reprinted as [楊小濱] 〈今天的 “今天派” 詩歌〉 [The Poetry of the “Today School" Today], in 《今天》1995-4: 244-261)

1999: 《历史与修辞》[History and Rhetoric], 兰州: 敦煌文艺

YaoJiahua 姚家华 (ed). 1989: 《朦胧诗论争集》[Essays on the Polemic over Obscure Poetry], 北京: 学苑

Yeh, Michelle. 1991 a: Modern Chinese Poetry: Theory and Practice since 1917, New Haven etc: Yale UP

1991b: Xi Mi 奚密,〈差異的憂慮: 一個回響〉 [The Anxiety of Difference: A Rejoinder], in 《今天》1991-1: 94-96

1991c: "Nature's Child and the Frustrated Urbanite: Expressions of the Self in Contemporary Chinese Poetry," in World Literature Today 65-3: 405-409

_ (ed \& transl) 1992a: Anthology of Modern Chinese Poetry, New Haven etc: Yale UP

1992b: "Light a Lamp in a Rock: Experimental Poetry in Contemporary China," in Modern China 18-4: 379-409

1993a: Xi Mi 奚密,〈海子《亞洲銅》探析〉 [A Tentative Analysis of Haizi’s «Asia Bronze»], in 《今天》1993-2: 123-132

1993b: Xi Mi 奚密, “落地生根” 還是 “落葉歸根”? 海外中文詩隨想〉

["Fall to the Ground and Take Root" or "Falling Leaves Returning to the Root"? Thoughts on Overseas Poetry in Chinese], in 《中時晚報》時代副刊, 20 June 1993 (reprinted in奚密, 《現當代詩文錄》[Essays on Modern and Contemporary Poetry], 台北, 1998: 聯合文學: 264-278) 
1994: Xi Mi 奚密〈死亡: 大陆与台湾地区近期诗作的共同主题〉 Death: A Common Theme in Recent Poetry from Mainland China and the Taiwan Area], in 《诗探索》1994-3: 36-54

1995: "Death of the Poet: Poetry and Society in Contemporary China and Taiwan," in Sung-sheng Yvonne Chang \& Yeh (eds), Contemporary Chinese Literature: Crossing the Boundaries, a special issue of Literature East \& West: 43-62 (reprinted with minor revisions in Chi \& Wang 2000: 216-238)

- 1996a: "The 'Cult of Poetry' in Contemporary China," in Fournal of Asian Studies 55-1: 51-80 (reprinted in Zhang Yingjin 1998: 188-217) 1996b: Xi Mi 奚密,〈北島: 我在語言中漂流〉[Bei Dao: I Drift in Language], in《自由時報》, 10-11 October 1996

1998a: Xi Mi 奚密, 〈诗与戏剧的互动: 于坚《0档案》探微〉 [Exploring Interactions of Poem and Play: Yu Jian's «File 0»], in 《诗探索》1998-3: 102-114

1998b: "International Theory and the Transnational Critic: China in the Age of Multiculturalism," in boundary 2 25-3: 193-222 (reprinted in Chow 2000: 251-280)

2000a: "Chinese Postmodernism and the Cultural Politics of Modern Chinese Poetry," in Wen-hsin Yeh (ed), Cross-Cultural Readings of Chineseness: Narratives, Images and Interpretations of the 1990s, Berkeley: Institute of East Asian Studies, University of California at Berkeley: 100-127

2000b: "From Surrealism to Nature Poetics: A Study of Prose Poetry from Taiwan," in Fournal of Modern Literature in Chinese 3-2: 117-156

2001: "Frontier Taiwan: An Introduction," in Yeh \& N G D Malmqvist (eds), Frontier Taiwean: An Anthology of Modern Chinese Poetry, New York: Columbia UP: $1-53$

2003: "Misty Poetry," in Mostow et al 2003: 520-526

2005: "The Poet as Mad Genius: Between Stereotype and Archetype," in Fournal of Modern Literature in Chinese 6-2/7-1: 119-144

2007a: "Anxiety and Liberation: Notes on the Recent Chinese Poetry Scene," in World Literature Today 81-5: 28-35

2007b: “'There Are No Camels in the Koran': What Is Modern about Modern Chinese Poetry?", in Lupke 2007: 9-26 and 219-232

Yemen 也门. 2001: 〈一块提醒哭泣的手帕: 王家新批判〉 [A Handkerchief for Reminding Yourself to Cry: Criticizing Wang Jiaxin], in Yi et al 2001: 287-320 (pseudonym of Yi Sha)

Yi Sha 伊沙. 1994: 《饿死诗人》 [Starve the Poets], 北京: 中国华侨

1999a: 《我终于理解了你的拒绝》 [I Finally Understand Your Refusal], 西 宁: 青海人民

1999b: 〈两个问题和一个背景: 我所经历的盘峰诗会〉 [Two Questions against One Background: The Panfeng Poetry Conference as I Experienced It], in《诗参考》1999: 75-81

2001a:〈现场直击: 2000 年中国新诗关键词〉 [On-the-Spot Direct Attack:

Keywords for the Year 2000 in China's New Poetry], in《芙蓉》2001-2: 123-129

- 2001b: 〈我所理解的下半身和我〉 [The Lower Body as I Understand It and ], in 《下半身》1: 113-114

2003:《伊沙诗选》 [Selected Poems by Yi Sha], 西宁: 青海人民

et al. 2000: Yi Sha, Xu Jiang \& Qin Bazi 伊沙、徐江、秦巴子, 《时尚杀

手: 三剑客挑战时尚》 [Assassins of Fashion: Three Musketeers Challenging Fashion], 广州: 花城 et al. 2001: Yi Sha, Zhang Hong, Xu Jiang, Qin Bazi \& Shen Haobo 伊沙、 
张闪、徐江、秦巴子、沈浩波, 《十诗人批判书》[Criticizing Ten Poets], 长 春: 时代文艺 - see also Yemen

Yin Lichuan 尹丽川. 2001: 《再舒服一些》[Make It Feel Even Better], 北京: 中国 青年

2006:《因果》[Cause and Effect], 福州: 海风

\& Bradbury, Steve. 2005: "Have Net, Will Travel: Is This the New Face of Chinese Poetry? PRC Poet and Head-Turner Yin Lichuan Talks about Her Image, Her Verse, and Publishing on the Web," in POTS, 21 October 2005: 17-18 (interview)

\& That's Beijing. 2004: "Beijing Writers Face a Dilemma," in China Daily, 2 April 2004 (interview, online, see also p475)

Yip Wai-lim. 1985: "Crisis Poetry: An Introduction to Yang Lian, Jiang He and Misty Poetry," in Renditions 23: 120-130

Yiping 一平. 2003: 〈孤立之境: 读北岛的诗〉 [The Predicament of Standing Alone: Reading Bei Dao's Poetry], in 《诗探索》2003-3/4: 144-163

Yu Hong 余虹. 1999:〈神・语・诗〉 [The Divine-Language-Poetry], in Cui 1999a: 111-121 (dated 1992)

Yu Jian 于坚. 1986:〈青年诗人谈诗: 于坚〉 [Young Poets on Poetry: Yu Jian], in《诗刊》1986-11: 31 1989a: 《于坚诗六十首》 [Sixty Poems by Yu Jian], 昆明: 云南人民 1989b: 《阳光下的棕㭣树》 [Palm Trees in the Sun], 昆明 (unofficial publication) cation)

1989c:《作品，1988-1989》[Works，1988-1989]，昆明 (unofficial publi1989d: 〈重建诗歌精神〉 [Rebuild the Spirit of Poetry], in《滇池》1989-6: 62-64

- 1990:《诗集, 1989-1990》[Poems, 1989-1990], 昆明 (unofficial publication) 1991: 〈拒绝隐喻〉 [Reject Metaphor], in Wu Sijing 1993: 308-312

1993: 《对一只乌鸦的命名》 [The Naming of a Crow], 昆明: 国际文化

1994: 〈0档案〉 [File 0], in 《大家》1: 48-58

1995a: (于堅)〈0檔案〉 [File 0], in《現代詩》23: 1-11

1995b: (于堅)《戲劇車間〈零檔案〉》[Theater Workshop: «File Zero»], 北京, 戲劇車間 (unofficial publication, original in full-form characters)

1995c:〈传统, 隐喻及其他〉 [Tradition, Metaphor and Other Things], in 《诗探索》1995-2: 137-141

69-75

1996: "Four Poems by Yu Jian," translated by Simon Patton, in Renditions 46:

1997a: 〈从隐喻后退: 作为方法的诗歌〉 [Retreat from Metaphor: Poetry as Method], in 《作家》1997-3: 68-73

- 1997b: 《棕皮手记》 [Brown Notebook], 上海: 东方

1998a: 〈诗歌之舌的硬与软: 关于当代诗歌的两类语言向度〉 [The Hard

and Soft of the Tongue of Poetry: On Two Different Directions in the Language

of Contemporary Poetry], in 《诗探索》1998-1: 1-18

1998b: 《王中文化奖: 首届获奖者诗人于坚》 [Poet Yu Jian, Laureate of the

First Wang Zhong Culture Award], 昆明 (unofficial publication)

1999a: (于堅) 《一枚穿過天空的釘子》[A Nail through the Sky], 台北: 唐山 1999b:〈穿越汉语的诗歌之光〉 [The Light of Poetry, Cutting through the

Chinese Language], in Yang Ke 杨克 (ed), 《1998 中国新诗年鉴》[1998 Year-

book of China's New Poetry], 广州: 花城: 1-17

1999c: 〈诗人及其命运〉 [The Poet and His Fate], in 《大家》1999-4: 80-83

2000: 《于坚的诗》 [The Poetry of Yu Jian], 北京: 人民文学 
2001a: 《诗歌 •便条集1996-1999: 1-216》 Poetry: Collected Notes，19961999: 1-216], 昆明: 云南人民

2001b: 〈诗言体〉 [Poetry Articulates the Body], in 《芙蓉》2001-3: 69-75 (reprinted in 《诗江湖》1: 52-59)

2003: 《诗集与图像2000-2002》[Poems and Images, 2000-2002], 西宁: 青 海人民

2004: 《于坚集》 [Collected Works of Yu Jian], 共五册, 昆明: 云南人民 (see Yu Jian 2004a, 2004b, 2004c, 2004d, 2004e)

-2004a: 《一枚穿过天空的钉子: 诗集, 1975-2000》 [A Nail through the Sky:

Poems, 1975-2000], in Yu Jian 2004

2004b: 《0档案: 长诗七部与便条集》[File 0: Seven Long Poems and Collected Notes], in Yu Jian 2004

2004c: 《人间笔记: 散文》 [Notes from the Human World: Short Prose], in Yu Jian 2004

2004d: 《正在眼前的事物: 散文》 [Objects Right in Front of Your Eyes:

Short Prose], in Yu Jian 2004

2004e: 《拒绝隐喻: 棕皮手记・评论 - 访谈》 Reject Metaphor: Brown Notebook-Criticism-Interviews], in Yu Jian 2004 征

2006a: 《只有大海苍茫如幕》[Only the Sea, Vast Like a Canopy], 北京: 长 - 2006b: 《八十八张便条: 便条集1996-2005选》 [Eighty-Eight Notes: Selected

Notes 1996-2005], New York: 诗歌报 / 惠特曼出版社-Walt Whitman Literature Fund

\& De Meyer, Jan A M. 1995: "Yu Jian: ik heb China nodig" [Yu Jian: I Need China], in Poëziekrant 1995-6: 28-30 (interview)

\& \& Han Dong 韩东. 1988: 〈在太原的谈话〉 [A Conversation in Taiyuan], in《作家》1988-4: 75-77

\& Jin Xiaofeng 金小风. 2002:〈于坚访谈〉 [nterview with Yu Jian], in《诗 参考》19/20: 211-219

\& T Tao Naikan 陶乃㑆. 1999: 〈抱着一块石头沉到底〉 [Clutch a Stone and

Sink to the Bottom], in 《湖南文学》1999-7: 70-80 (interview)

- \& Xie Youshun 谢有顺. 2001: 〈真正的写作都是后退的〉 [What All True

Writing Does Is to Retreat], in 《南方文坛》2001-3: 28-33

\& \& Zhu Wen 朱文1993: 〈回答诗人朱文的二十五个问题〉[Answers to

Twenty-Five Questions by Poet Zhu Wen], 昆明 / 南京 (interview, unofficially circulated manuscript)

－\& Zhu Wen 朱文 1994: 〈回答二十五个问题〉 [Answers to Twenty-Five Questions], in 《他们》7: 124-134 (interview: published version of Yu Jian \& Zhu 1993, with interviewer Zhu Wen unidentified)

Yu Liwen 余麗文. 2006: 〈邊緣與中心的對話: 解構于堅與華鳴〉 [A Dialogue of the Margins and the Center: Deconstructing Yu Jian and Hua Ming], in 《創世 紀詩雜誌》147: 162-182

Yu, Pauline et al (eds). 2000: Pauline Yu, Peter Bol, Stephen Owen \& Willard Peterson, Ways with Words: Writing about Reading Texts from Early China, Berkeley etc: University of California Press

Yu Xugang 余徐刚. 2004:《海子传: 诗歌英雄》 [A Biography of Haizi: Hero of Poetry], 南京: 江苏文艺

Yuan Youming 袁幼鸣. 1992: 《“汪国真现象” 备忘录》 [Memorandum on “the Wang Guozhen Phenomenon”], 北京: 学林

Zang Di 蔵棣. 1994:〈王家新: 承受中的汉语〉 [Wang Jiaxin: Testing the Endurance of the Chinese Language], in 《诗探索》1994-4: 103-110 
Zhang Er \& Chen Dongdong (eds). 2007: Another Kind of Nation: An Anthology of Contemporary Chinese Poetry, bilingual, various translators, Jersey City: Talisman House

Zeng Hong. 2005: "Foreword," in Haizi 2005: xiii-xxiii

Zhang Hong 张闳. 2003: 《声音的诗学》 [The Poetics of Voice], 北京: 中国人民大 学

Zhang Hongming 章宏明. 1990: 〈对“新诗潮” 的透视〉 [“New Tide Poetry” Unmasked], in 《文艺报》, 17 November 1990

Zhang, Jeanne Hong. 2004: Jeanne Hong Zhang, The Invention of a Discourse: Women's Poetry from Contemporary China, Leiden: CNWS

Zhang Longxi. 1992: The Tao and the Logos: Literary Hermeneutics, East and West, Durham etc: Duke UP

1993: "Out of the Cultural Ghetto: Theory, Politics and the Study of Chinese Literature," in Modern China 19-1: 71-101

Zhang Ning 张柠. 1999: 〈《0档案》词语集中营〉 [《File 0», a Concentration Camp of Words], in 《作家》1999-9: 41-50

Zhang Qinghua 张清华. 1997: 《中国当代先锋文学思潮论》[On Trends of Thought in Contemporary Chinese Avant-Garde Literature], 南京: 江苏文艺 1999: 〈“在幻像和流放中创造了伟大的诗歌”〉 [“In Phantasms and Exile Create Poetry of Greatness"], in Cui 1999a: 172-186

2002: 〈序〉 [Preface], in 《2001年中国最佳诗歌》[China's Best Poetry of 2001], 沈阳: 春风文艺: 9-24

Zhang Shuguang 张曙光. 1998: 《小丑的花格外衣》[The Clown's Checkered Facade], 北京: 文化艺术

1999: 〈关于诗的谈话: 对江涛书面提问的回答〉 [A Conversation about Poetry: In Reply to Jiang Tao's Written Questions], in Sun Wenbo, Zang Di \& Xiao Kaiyu 孙文波、藏棣、肖开愚 (eds), 《语言: 形式的命名》, 北京: 人民 文学: 235-250

Zhang Xudong. 1997: Chinese Modernism in the Era of Reforms: Cultural Fever, Avant-Garde Fiction and the New Chinese Cinema, Durham etc: Duke UP

Zhang Yingjin. 1993: "Re-envisioning the Institution of Modern Chinese Literature Studies: Strategies of Positionality and Self-Reflexivity," in positions 1-3: 816-832

1998: China in a Polycentric World: Essays in Chinese Comparative Literature, Stanford: Stanford UP

Zhang Zao 張柬. 1999: 〈當天上掉下來一個鎖匠.... 〉 [When from Heaven Fell a Locksmith....], in北島, 《開鎖》, 台北: 九歌, 1999: 7-29

2004: Zhang Zao, Auf der Suche nach poetischer Modernität: Die Neue Lyrik Chinas nach 1919 [In Search of Poetic Modernity: China's New Poetry after 1919], PhD thesis, Eberhard-Karls-Universität Tübingen

— \& Song Lin 宋琳 (eds). 2002: 《空白練習曲: 〈今天〉十年詩選》 Blank Études: Selected Poems from Ten Years of Today], 香港 etc: Oxford UP

Zhang Zhen. 1999a: "The World Map of Haunting Dreams: Post-1989 Chinese Women's Diaspora Writings," in Mayfair Mei-hui Yang (ed), Spaces of Their Own: Women's Public Sphere in Transnational China, Minneapolis etc: University of Minnesota Press: $308-335$

1999b: "The Jet Lag of a Migratory Bird: Border Crossings toward / from 'The Land That Is Not',' in Sharon K Hom (ed), Chinese Women Traversing Diaspora: Memoirs, Essays, and Poetry, New York etc: Garland: 51-75

Zhao, Henry Y H. 1997a: Zhao Yiheng 赵毅衡, 〈“流外丧志”, 而后有文学: 关于 海外大陆小说的几点观察〉 [“Those Who Live in Exile Lose Belief," But Create Literature: Some Remarks on Fictional Works by Chinese Writers Living Overseas], in Wan Zhi 1997a: 115-128 
1997b: Zhao Yiheng, “'Those Who Live in Exile Lose Belief,' But Create Literature: Some Remarks on Fictional Works by Chinese Writers Living Overseas," in Wan Zhi 1997b: 130-149

-1999: "The Poetics of Death," in Li Xia 1999: 9-20

2003: "The River Fans Out: Chinese Fiction since the Late 1970s," in the European Review 11-2: 193-208

- \& Cayley, John (eds). 1994: Under-Sky UnderGround: Chinese Writing Today: I, London: Wellsweep

_ \& Cayley, John (eds). 1996: Abandoned Wine: Chinese Writing Today: II, London: Wellsweep

Cet al (eds). 2000: Henry Zhao, Yanbing Chen \& John Rosenwald, Fissures: Chinese Writing Today, Brookline: Zephyr Press

Zhao Qiguang. 2005: "Preface: In Memory of Hai Zi," in Haizi 2005: i-xi

Zhao Xun 赵㻏. 2002: 《还需要多久, 一场大雪才能从写作中升起: 王家新的《伦 敦随笔》解读〉 [How Long until A Heavy Snow Will Rise from Writing? Wang Jiaxin's «London Jottings»: An Interpretation], in Hong 2002: 27-52

Zhao Yiheng 赵毅衡: see Zhao, Henry Y H

Zheng Yi et al (eds). 2005: Zheng Yi, Su Wei, Wan Zhi \& Huang Heqing 鄭義、蘇 煒、萬之、黃河清, 《不死的流亡者》[The Undying Exile], 台北: INK

Zhong Ming 钟鸣. 1991: 〈中间地带〉 Intermediary Zone], in Haizi \& Luo 1991: 343-346 (dated 1989)

1998:《旁观者》[Spectator], 共三册, 海口: 海南 see also Shi Jile

Zhongdao 中岛 (ed). 1998: 《伊沙这个鬼: 伊沙的诗及相关评论集》 [That Devil of an Yi Sha: The Poetry of Yi Sha and Collected Reviews], 北京: 《诗参考》编辑 部 (unofficial publication)

Zhongguo Shehui Kexueyuan Yuyan Yanjiusuo Cidianshi 中国社会科学院语言研 究所词典室 (ed). 1996:《现代汉语词典》[Dictionary of Modern Chinese], 北 京: 商务 (revised edition)

Zhou Lunyou 周倫佑. 1999: 《在刀鋒上完成的句法旋轉換》[Syntactic Transformation Completed on the Edge of a Knife], 台北: 唐山

Zhou Yubing 周玉冰. 2005: 《面朝大海 春暖花开: 海子的诗情人生》 [Face to the Sea Spring Warmth Flower Glee: Haizi’s Poetic Life], 合肥: 安徽文艺

Zhu Dake 朱大可. 1999: 〈先知之门〉 [Door of the Prophets], in Cui 1999a: 122142 (dated 1991)

一 2006: 《流讯的盛宴: 当代中国的流讯叙事》[The Hooligan Banquet: Contemporary China's Hooligan Narrative], 北京: 新星

Zhu Wen 朱文. 1998: 〈断裂: 一份问卷和五十六份答卷〉 [Rupture: One Set of Questions, and Fifty-Six Sets of Answers], in 《北京文学》 1998-10: 19-40, 47

Zhuang Rouyu 莊柔玉. 1993: 《中國當代朦朧詩研究: 從困境到求索》 [A Study of Contemporary Chinese Obscure Poetry: From Predicament to Exploration], 台北: 大安

Zou Jianjun 邹建军. 1999: 〈试论海子的诗歌创作〉 [Tentative Remarks on Haizi's Poetry], in Cui 1999a: 232-244

Zou Jingzhi 邹静之. 1991: 〈正午的黑暗〉 [Darkness at Noon], in Haizi \& Luo 1991: 332-334 (dated 1989) 